UNITED STATES

DEPARTMENT OF THE TNTERIOR

GEOLOGICAL SURVEY

\title{
SUMMARY OF REFERENCES TO MINERAL OCCURRENCES \\ (OTHER THAN MINERAL FUELS AND CONSTRUCTION MATERIALS) \\ IN THE BRADFIEZD CANAL QUADRANGLE, ALASKA
}

By

Edward H. Cobb

Open-File Report 78-922

1978

This report is preliminary and has not been edlted or reviewed for conformlty with Geological Survey standards and nomenclature. 


\section{Introduction}

These sumaries of references are designed to ald in library research on metallic and nonmetallic (other than mineral fuels and construction materlals) mineral occurrences in the Bradfield Canal quadrangle, Alaska. All references to reports of the Geological Survey and to most reports of the U.S. Bureau of Mines, and to most reports of the State of Alaska D Iston of Geologlcal and Geophysical Surveys and its predecessor state and Terrttorial agencies released before July 1, 1978, are sumarized. Certaln, mainly statistical, reports such as the annual Minerals Yearbook of the U.S. Bureau of Mlnes and wost blennial and annual reports of the State of Alaska Division of Geological and Geophysical Surveys and its predecessor State and Territorial agencies are not included.

Thts report is divided inco three parts: a section made up of sumwaries of references arranged alphabetically first by occurrence name; a section that lists synonyms for names in the first section, claim names, and the names of operators and ownexs of mines and prospects; and a section that lists, by author, all references summarized in the first section. 


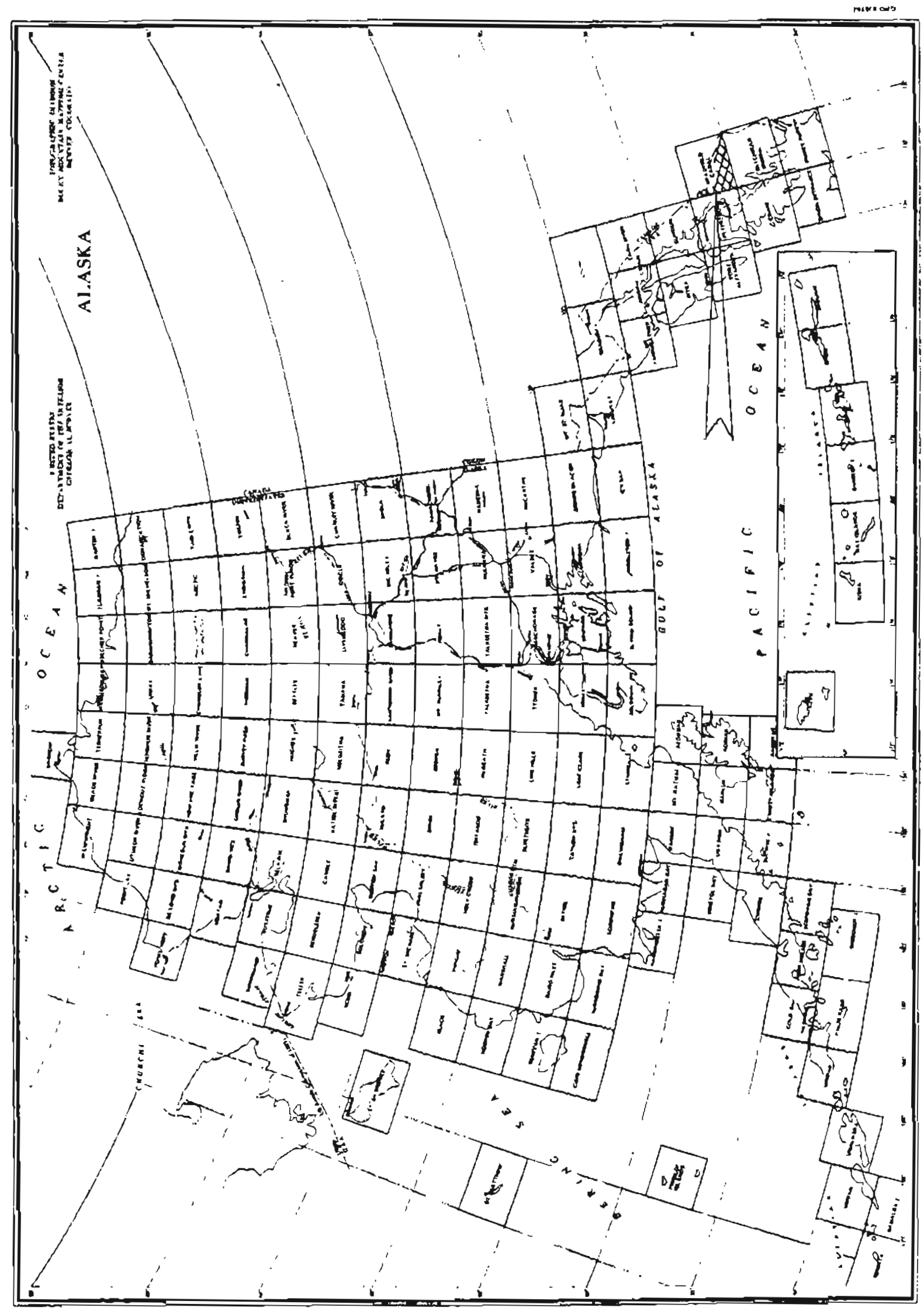




\section{Sumaries of References}

For each mineral occurrence there is a page that gives the name of the occurrence; the mineral comodities present (Iisted alphabetically for metallic comodities and then for nonmetallic comodities) (RE is used for all rare-earth elements in minerals other than monazite]; the mining distrlct (Ransome and Kerns, 1954) in which the occurrence ts located; the name of the 1:250,000-scale copographic quadrangle; coordinates (as described by Cabb and Kachadoorlan, 1961, p. 3-4); the metallic mineral resources map number $(M F-418)$ and the occurrence number on that map if the occurrence is shown; and the latitude and longitude of che occurrence. These data, presented at the top of the page, are followed by a short, general summary of the published information on the occurtence. This is followed (continued on additional pages, If necessary) by wore detailed sumarles, arranged chronologically, of all references to the occurrence. Material in brackets is interprettve or explanatory and is not in the summartzed zeference.

Proper names of mines, prospects, and other mineral occurrences uswally are given if such aames appear in the reports summarized. If a depostc does not have such a name or has been known by many names, but is near a named geographic feature, the name of that feature is shown in parentheses In lieu of a proper name. If a part of a proper name is not always used in a reference, that part of the rame is shown in parentheses. This is most comon in company names and in place names with tolnor variations in spelling. 
Cltatlons are given in standard bibliographic format with the exception that references to reports and maps to numbered publication series also show, in parentheses, an abbreviacion for the report or map serles and the report or map number. Abbreviations used are:

$\begin{array}{ll}\text { B } & \text { U.S. Geological Survey Bulletin } \\ \text { IC } & \text { U.S. Bureau of Mines Information Clrcular } \\ \text { OF } & \text { U.S. Geological Survey Open-File Report (numbers are } \\ & \text { Informal and used only within the Alaskan Geology Branch } \\ & \text { of the U.S. Geological Survey) } \\ \text { MF } & \text { U.S. Geological Survey Miscellaneous Field Studies Map } \\ \text { P } & \text { U.S. Geological Survey Professional Paper } \\ \text { RI } & \text { U.S. Bureau of Mines Report of Investigations }\end{array}$

Sumarles are as I made them while reading the cited reports. I made no attemp to use complete gentences and did not edit for gramatical consisrency, although I have trled to edit out ambiguities.

References cited only in thege introductory paragraphs are:

Cobb, E. H, and Kachadoorian, Reuben, 1961, Index of metallic and noumetallic mineral deposits of Alaska complied from published reports of Federal and State agencies through 1959: U.S. Geologlcal Survey Bulletin $1139,363 \mathrm{p}$. Ransome, A. L., and Kerns, W. H., 1954, Names and definitions of reglons, districts, and subdistricts in Alaska (used by the Bureau of Mines in statistical and economlc studies covering the mineral industry of the Terrfcory): U.S. Bureau of Mines Information Circular 7679, 91 p. 
Alaska-Premier

Hyder district

$M F-418,10 c .23$
Copper, Gold, Lead, Silver, Tungsten, Zinc

Bradfield Canal (19.15,0.7)

$56^{\circ} 02^{\prime} \mathrm{N}, 130^{\circ} 03^{\prime} \mathrm{W}$

Summary: Felsite sheets (e1ther quartz porphyry stlls or facies of greenstone) in country rock that is mainly greenstone with intercalated slace and graywacke contain quartz veins in shattered zones. Velns contain pyrite, sphalerite, galena, pyrrhotite, chalcopyrite, tetrahedrite, arsenopyrite, conslderable gold, and rare scheelite grains. Sowe selected samples contain as much as 35 o2, a ton gold; some of fractured felsite contains \$2-\$3 [about 0.097-0.145 02.) a ton gold and about $1 \mathrm{oz}$, a ton sllver. Some exploration in late $1920^{\prime} \mathrm{s}$.

Buddington, 1925 (B 773), p. 74 -- Quartz veins and velnlike replacement bodies in quartz porphyry (felsite) contain pyrite, galena, sphalerite, chalcopyrite, and pyrrhotlte.

p. 78-79 -- Preliminary to Buddington, 1929 (B 807).

Buddington, 1929 (B 807), P. 85-86 -- Country rock greenstone with Intercalated slate and graywacke; 3 sheets of felsite, whlch may be either quartz porphyry sills or facies of greenstone. Quartz veins in shattered zones in felstte sheets contain pyrlte, sphalerite, galena, pyrrhotite and considerable gold. One pocket also concains chalcopyrite. As much as $35 \mathrm{oz}$. a ton gold $1 \mathrm{n}$ some selected samples. 2 felsite sheets explored by tunnels; some of fractured felsite contains an average of $\$ 2-\$ 3$ a ton in gold and about 1 oz. a ton sliver. A mineralized shear zone in a felsite sheet about $3 \mathrm{ft}$. wide contains pyr1te, galena, sphalerite, chalcopyrite, tetrahedrite, pyrrhotite, and arsenopyrite.

Byers and Sainsbury, 1956 (B 1024-F), P. 140 -- Rare scheelite grains. 
(Banded Mtr.)

Hyder district

$M F-418,10 c .5$
Gold(?), Lead(?), S1iver(?)

Bradfleld Canal (15.2, 0.7)

$56^{\circ} 02^{\prime} \mathrm{N}, 130^{\circ} 27^{\prime} \mathrm{W}$

Summary: Country rock largely graywacke cut by altered gabbro dikes, RIch ore reported to have been discovered about 1929 and some work done during the next few pears. No data on ore deposits; assumed to be pocentially valuable for gold; silver and lead also possibilities. See also: Edelweiss, Glacier.

Smith, 1932 (B 824), p. 17 -- Report of finding rfch ore in 1929 set off a small stampede.

Smtth, 1933 (B 836), p. 15 -- Continued prospecting said to have been encouraging, 1930.

Smith, 1933 (B 844-A), p. 17 -- Drift being driven, 1931.

Swith, 1934 (B $857-A$ ), P. 16 -- Development, 1932.

Smith, 1934 (B 864-A), p. 16 - Development, 1933.

Berg and Cobb, 1967 ( 8 1246), p. 182 -- Graywacke cut by altered gabbro dikes in area. 
Bartholf

Hyder district

MF-418, 10c. 19
Copper, Lead

Bradfleld Canal (18.85, 1.65)

$56^{\circ} 05^{\prime} \mathrm{N}, 130^{\circ} 04^{\prime} \mathrm{W}$

Sumary: Quartz vein (average thickness $6 \mathrm{in.}$ ) contains disseminated chalcopyrite and local shoots of pyrite and galena. Geologic map (pl. 2) shows country rock to be Texas Creek Granodiorite. Most of property on Camadian side of boundary.

Buddington, 1929 (B 807), p. 92-93 -- Quartz vein as much as a foot (average 6 10.) wide contalns disgeminated chalcopyrite and local shoots of pyrtte and galena; barite plates common. Dein strikes $\mathrm{N} 18^{\circ} \mathrm{W}$ and dips $55^{\circ}$ W. Most of property on Canadian side of boundary. 
Bertha

Hyder district

$M F-418,10 c \cdot 23$
Copper, Lead, Zinc

Bradfield Canal (19.15, 0.7$)$

$56^{\circ} 02^{\prime} \mathrm{N}, 130^{\circ} 03^{\prime} \mathrm{W}$

Sumary: Disseminated pyrite, chalcopyrite, galena, and sphalertte in a lode at least $15 \mathrm{ft}$. Wide in silictfied schistose tuff. See also Daly-Alaska, of which Bertha may have become a part.

Chapin, 1916 (B 642), p. 97 - Bertha and Western claims being developed In 1915 on a NE-trending lode at leagt $15 \mathrm{ft}$. wide as exposed in a surface cut; in sillcified schistose tuff; disseminated pyrite, chaicopyrite, galena, and sphalertte.

Mertle, 1921 (B 714), p. 142 - Quotation from above. 
Bevacque

Hyder discrict

$M F-418,100,13$
Gold, Lead, Silver

Bradfield Canal (17.35, 1.0)

$56^{\circ} 03^{\prime} \mathrm{N}, 130^{\circ} 13^{\prime} \mathrm{H}$

Sumbary: Ore shoots in ve1n reported to be as much as $3-1 / 2 \mathrm{ft}$. thick sald to yield good assays in gold, sliver, and lead. See also North SLar.

Buddington, 1926 (B 783), p. 53 - Vein reported to be as much as 3-1/2 ft. thlck and to have been traced for several hundred feet. Ore shoots ylelding good assays in gold, sllver, and lead reported. 
Blasher

Hyder district

$M F-418$, loc. 9
Copper, Gold, Lead, Molybdenum, Silver, Zínc

Bradfield Canal (16.9, 1.15)

$56^{\circ} 03^{\prime} \mathrm{N}, 130^{\circ} 16^{\prime} \mathrm{W}$

Summary: Quartz vein 21-61 cm thick in quartzite, hornfels, and quartz monzonite (cupola of Texas Creek Granodiorlte) contains chalcopyr1ce, galena, sphalerice, pyrrhotite, pyrite, and a little molybdenite. Explored by short drift, pits, and dlamond drill holes. Has been recent work. No recorded production. See also Morning.

Buddington, 1929 (B 807), p. 100 -- Shattered and fissured zone in quartzite near contact with Texas Creek Quarcz diorite contalns a quartz vein about $4 \mathrm{ft}$. thlck and many mineralized quartz stringers, which carry galena, pyrite, sphalerite, and a little chalcopyrite. Zone strikes $\mathrm{N} 20^{\circ} \mathrm{W}, \mathrm{dips} 45^{\circ} \mathrm{E}$, and has been traced 500 yds. Short adit driven in argllltte to undercut lode encountered quartz veinlets containing disseminated molybdenite.

Smith, 1942 (B 926-C), p. 171 -- Reference to above.

Byers and Sainsbury, 1956 (B 1024-F), P. 140 -- Search with ultraviolet lamp did not discloge any scheelite.

Berg and others, 1977 (B 1403), p. 38-39 - Quartz vein 21-61 cm thick exposed along strike for $42 \mathrm{~m}$; In quartzite and hornfels of Hazelton(?) Gp. and Texas Creek Granodiorite; strikes $\mathrm{N} 50^{\circ} \mathrm{W}$, dips $60^{\circ}-70^{\circ} \mathrm{NE}$; contains chalcopyrite, galena, sphalerite, pyrrhottte, pyrite, and molybdenlte. Recent work comprises short drift and pits. First staked, 1923; restaked as part of Lone Star, 1970. P. 72 -- Data on history of claims.

p. 85-89 -- Deta1led description of prospect; data sumarized in table on p. 58-59 -- Weighted average of assay data $150.93 \% \mathrm{Cu}, 1.15 \%$ $\mathrm{Pb}, 1.25 \% \mathrm{zn}, 0.002 \% \mathrm{Mo}, 4.4 \mathrm{oz}$. a con Ag, and $0.016 \mathrm{oz}$, a con $\mathrm{Au}$ (over sample width of $37 \mathrm{~cm}$ ). Igneous rock is quartz monzonite; probably swall cupola of Texas Creek Granodiorite. 
Bluebird

Hyder district

$M F-418$, loc. 22
Copper, Lead, Molybdenum, Tungstea

Bradfield Canal (18.9, 0.55)

$56^{\circ} 01^{\prime} \mathrm{N}, 130^{\circ} 04^{\prime} \mathrm{W}$

Sumbary: Quartz vein 4 in. thick in granodiorite contains sparsely dissem inated pyrite, chalcopyrite, galena, and scheelite; molybdenite along walls. Estimated to contain $0.5 \% \mathrm{WO}_{3}$.

Byers and Salnsbury, 1956 (B 1024-F), p. 139-140-- Claim 1ocared in 1942 on a quartz vein In Texas Creek Granodlorite about 1,500 ft. from contact with rocks of Hazelton $G p$. Veln is $4 \mathrm{fn}$. wide and exposed for only a few feet. Mainly quartz with sparsely disseminated pyrite, chalcopyrite, galena, and scheelite in the central part and molybdenite along walls. Hand spectmens contained an estimated $0.5 \% \mathrm{WO}_{3}$. 
Border

Hyder district

MF $-428,10 c .21$
Copper, Lead, Zinc

Bradfield Canal (19.15, 1.05)

$56^{\circ} 03^{\prime} \mathrm{N}, 130^{\circ} 03^{\prime} \mathrm{W}$

Sumary: Gash veins in fissure zone in slate and graywacke becween 3 granodiorite porphyry dikes contain quartz and shoots as much as 6 in. thick of galena, sphalerite, pyrite, and a little chalcopyrite. 70-ft. adit.

Buddington, 1929 (B 807), p. 90 - Mineralized fissure zone between 2 granodlorite porphyry dikes is in slate and graywacke and contains gash veins of quartz with galena, pyr1te, sphalerite, and a little chalcopyrite and constderable carbonate. Sulfides in shoots as much as 6 in. wide. Adlt has been driven $70 \mathrm{ft}$. 
Brigadier

Hyder diatrict

$M F-418,10 c .22$
Gold, Lead, Silver, Tungsten

Bradfield Cana1 (18.9,0.55)

$56^{\circ} 01^{\prime} \mathrm{N}, 130^{\circ} 04^{\prime} \mathrm{W}$

Summary: Quartz velns $10 \mathrm{fn}$. to $3 \mathrm{ft}$. thick in granodiorite contain gold, silver, galena, pyrite, and rare grains of scheelite. Samples assayed $11.4 \%-14.1 \%$ lead, $0.24-0.6$ oz. a ton gold, and $10.2-20.6$ oz. a ton silver. Explored in late $1920^{\prime} \mathrm{s}$ by open cuts and a 25-ft. shaft. Includes reference to Butce group of claims.

Buddington, 1929 (B 807), p. 81 -- Quartz veins on Butce group of 6 clatms contain gold, silver, galena, and pyrite. Both of 2 velns have been traced for 400-500 $\mathrm{Et}$. and are $10 \mathrm{In}$. to $3 \mathrm{ft}$. wide. Assays of 2 samples Indicated $11.4 \%-14.1 \%$ lead, $0.24-0.6 \mathrm{oz}$. gold, and 10.2-20.6 oz. silver a ton. Explored by open cuts and a 25-ft. shaft. Geologic map (p1. 2) shows country rock as Texas Creek Granodiorite.

Byers and Salnsbury, 1956 (B 1024-F), P. 140 -- Rare grains of scheelite. 
Cantu (Mining Co.)

Hyder district

MF-418, Loc . 19
Copper, Gold, Lead, Sllver, Zinc; Barite

Bradfield Canal (18.85, 1.65$)$

$56^{\circ} 05^{\prime} \mathrm{N}, 130^{\circ} 04^{\prime} \mathrm{W}$

Summary: Councry rock is granodiorite near contact with greenstone and sedimentary rocks. Quartz veins as much as $3 \mathrm{ft}$. thick and small veinlets contaln galena, sphalerite, tetrahedrite (some very rich in silver), and generally sparse pyrite and chalcopyrite. In places barice makes up as much as 50\% of gangue. 20-ton test shipment of carefully selected ore to smelter in 1925 contained $0.175-0.30 \mathrm{oz}$. a ton gold, $13.80-31.05$ oz. a ton silver, $37.2 \%-44.1 \%$ lead, and $5.6 \%-12.2 \%$ zinc. No record of any other production.

Moffit, 1927 (B 792), p. 30 -- Test shtpment of 20 tons of high-grade lead ore carrylng gold and silver, 1925; newly discovered deposit.

Buddington, 1929 (B 807), p. 41 -- Barite is a common gangue mineral.

p. 43 -- Examle of quartz-fissure veins of lead-silver-gold type.

p. 91-92 -- Country rock is Texas Creek Granodiorite cut by quartz porphyry dikes; near contact between granodiorite and greenstone and sedimentary rocks of Hazelton Gp. Quartz velns ranging from a few Inches to $3 \mathrm{ft}$. In thickness and sma1l veinlets contain galena, sphalerite, tetrahedrite, and generally sparse pyrite and chalcopyrite; considerable barite in gangue, in places equal in amount to quartz. Test shipment of carefully selected ore sent to smelter; smelter assays showed 0.175-0.30 oz. gold and 13.80-31.05 0z. silver a ton, $37.20 \%-$ $44.1 \%$ lead, and $5.6 \%-12.2 \%$ zinc; gross values were $\$ 88.10$ and $\$ 108.79$ a ton. Assays of grab samples of sorted ore at property were generally comparable except that one sample high in tetrahedrite contained 61.2 oz. silver a ton. A grab sample from another veln $30-35 \mathrm{ft}$, wide and containing streaks and disseminations of pyrtte gave en assay of $0.8 \mathrm{oz}$. gold and $1.2 \mathrm{oz}$. sllver a ton.

Buddlngton and Chapin, 1929 (B 800), P. 324 -- Tetrahedrite present locally in considerable amounts.

Sulth, 1932 (B 824), p. 17 - Claims consolidated, 1929.

Smith, 1943 (B 864-A), p. 16 -- Steps taken toward refinancing; no work on ground, 1933.

Smith, 1938 (B 897-A), p. 19 -- Prospect1ng, 1936.

West and Benson, 1955 (B 1024-B), P. 30 -- Data from Buddington, 1929 (B 807), P. 43 .

gyers and Sainsbury, 1956 (8 1024-F), 0. 140 -- Examination with ultraviolet lamp falled to reveal scheeltte.

Berg and Cobb, 1967 (B 1246), p. 147 -- Some ore has been shipped. 
Hyder district

Bradfield Canal (16.8, I.55) $56^{\circ} 05^{\prime} \mathrm{N}, 130^{\circ} I 7^{\prime} \mathrm{W}$

Summary: Quartz veins in Hazelton(?) Gp. graywacke are as much as 1-2 m wide; contain mainly galena and sphalerite with smaller amounts of chalcopyrite, pyrite, and pyrrhotite and as much as $20.4 \mathrm{oz}$. a con silver, and a trace of gold. Very little development and no record of production.

Berg and others, 1977 (B 1403), p. 38-39 -- Quartz veln 1-2 m thick in graywacke of hazelton(?) Gp. strikes $\mathrm{N}$ to $\mathrm{N} 5^{\circ} \mathrm{E}$ and dips $50^{\circ} \mathrm{E}$. Carries sphalerite, galena, and chalcopyrite. First scaked in 1930. Explored by scripped area for $3 \mathrm{~m}$. Other smaller veins nearby. p. 90-91 - Quartz veins in rocks of Hazelton(?) Gp. have bands of sulfides, mainly sphalerite and galena with staller amounts of pyrite, pyrihotite, and chalcopyrite. Sample across sulfide zone in larger veln (about $1.5 \mathrm{~m}$ wide) concained $4.4 \mathrm{oz}$. a ton $\mathrm{Ag}, 0.27 \% \mathrm{Cu}$, $0.9 \% \mathrm{~Pb}$, and $35 \% \mathrm{zn}$. One analysis showed $0.05 \mathrm{ppm}$ gold. Sample of sulfide zone $6 \mathrm{~cm}$ wide from smaller vein contalned $20.4 \mathrm{oz}$, a ton Ag, $19 \% \mathrm{~Pb}, 9 \% \mathrm{Zn}$, and $0.02 \% \mathrm{Cu}$. 
Hyder district

Bradfield Canal ( $18.9,0.95$ )

MF $-418,10 c .20$

$$
56^{\circ} 03^{\prime} \mathrm{N}, 130^{\circ} 04^{\prime} \mathrm{W}
$$

Sumary: Sphalerite, galena, pyrite, and chalcopyrite disseminaced in sheared siliclfied porphyry. Assays reported to show small quanruties of gold and sllver.

Wegrgate, I922 (B 722), p. 129 -- Disseminated sulfides in sheared porphyry and granodiorite of batholith on Charles claim.

p. 139-140 -- Bedrock is sheared granite porphyry; cut by small barfen quartz veins. Sphalerice, galena, pyrite, and chalcopyrtce dissemlnated in silicified porphyry; assays reported to show swall quantities of gold and silver.

Buddington, 1925 (B 773), P. 87 - Reference to above. 
Chickamin

Hyder district

ME-418, 10C. 8
Copper, Leed, Zinc

Bradfield Canal (16.9, 1.5$)$

$56^{\circ} 04^{\prime} \mathrm{N}, 130^{\circ} 16^{\circ} \mathrm{W}$

Summary: Very little work done on flssured zone in graywacke that contains quartz mineralized with galena, chalcopyrite, sphalerite, pyrite, and a little pyrrhotite and terrahedrlte.

Buddington, 1929 (B 807), p. 100 -- Fissured zone in graywacke strikes $\mathrm{N} 25^{\circ} \mathrm{W}$ and dips $50^{\circ} \mathrm{NE}$; contains quartz stringers mineralized with galena, chalcopyrite, aphalerite, pyrite, and a little pyrrhotite and tetrahedrite. Very little work has been done; veins are exposed for only very short distance.

Berg and others, 1977 (B 1403), p. 38-39, 84 -- Data from above; prospect could not be found. 
(Chickamin R. Canyon)

Hyder district
RE

Bradfield Canal (14.5, 0.65)

$56^{\circ} 02^{\prime} \mathrm{N}, 130^{\circ} 31^{\prime} \mathrm{H}$

Sumary: Sphene and allanite are prominent accessory minerals in blorte quartz monzonice.

Sulth and others, 1977 (MF-825), smple 35009 -- Sphene and allanice are prominent accessory minerals in medium-grained leucocratic massive blotire quartz monzonlte. 
Copper King

Petersburg district

MF-418, loc. 1
Copper, Gold, Lead, Silver, Zine

Bradfield Canal (0.1, 8.25) approx. $56^{\circ} 28^{\prime} \mathrm{N}, 132^{\circ} 00^{\prime} \mathrm{W}$ approx.

Summary: Claim(s) staked $1 n 1906$ and restaked in 1951 on sulfide-bearing vein(?) reported to carry copper, lead, and zinc minerals and some gold and silver. Some references to this prospect may actually be to (Berg Basin) Petersburg quad. Includes references to Berg.

Chapin, 1916 (B 642), p. 78 -- Development on Berg claims, 1915. [This reference may really be to (Berg Basin) Petersburg quad.]

Chapin, 1918 (B 662), p. 75 -- Further development work, including an adit $300 \mathrm{ft}$. long, reported, 1916. [Reference may actually be to (Berg Basin) Petersburg quad. Maps here and in Chapin, 1916, both show prospect symbol in Bradfield Canal quad, however.]

Berg and Cobb, 1967 (B 1246), p. 192 -- Staked in 1906 and restaked in 1951. Sulfde-bearing vein(?) satd to conta1n copper, zinc, and lead minerals and to carry some gold and silver. 
Hydex districe

Bradfield Canal $(18.9,0.55)$

$M F-418,10 c .22$

$56^{\circ} 01^{\prime} \mathrm{N}, 130^{\circ} 04^{\prime} \mathrm{W}$

Sumary: Quartz velns and stringers in fissure zone in granodiorite carry galena, pyrice, a little chalcopyrite, and free gold. Wall rock impregnated with pyrite in places; fracture surfaces coated with pyrite and galena. Highest gold assay was about 5 oz. a ton; most conslderably lower. Exploration by surface excavations.

Buddington, 1929 ( $B$ 807), p. 81-82 -- Nartow but persistent fissure zone in Texas Creek granodiorite strikes $\mathrm{N} 50^{\circ} \mathrm{W}$ and dips $55^{\circ}-70^{\circ} \mathrm{NE}$; has been traced for about $350 \mathrm{Et}$. In open curs and strippings. Solld vein or stringers of quartz aggregate as tuch as $3 \mathrm{ft}$. in thickness and contain local shoors heavily mineralized with galena, some associated pyrite, and a little chalcopyrite; country rock impregated with pyrite; pyrtte and galena on fracture surfaces. Some small quartz stringers carry as much as $\$ 105$ [about $5 \mathrm{oz}$.] In free gold per rou; most are considerably leaner. 
Cripple Creek

Hyder district

$\mathrm{MF}-418$, loc. 22
Copper, Lead, Zinc

Bradfield Canal (18.9, 0.55$)$

$56^{\circ} 01^{\circ} \mathrm{N}, 130^{\circ} 04^{\prime} \mathrm{W}$

Summary: Large quartz vein in sheeted zone in granodlorite, breccia zone with quartz veinlets in pyrite-impregnated granodiorite, and several fissure zones in granodtorite contain pyrite, galena, sphalerite, chalcopyrtie, and terrahedrite. Deposit in sheeted zone explored by 45-Et. adit and a short crosscut. No data on probable content of silver and gold.

Buddington, 1925 ( 8 773), P. 74 -- Quartz E1ssure vein In granodiorite contains pyrite, galena, and chalcopyrtte.

p. 82-83 - Preliminary to Buddington, 1929 (B 807).

Buddington, 1929 (B 807), P. 83-84 - One deposit is a sheeted zone about 10-15 ft. wide in granodlorlte; large quartz veln along footwall; strikes $\mathrm{N} 73^{\circ} \mathrm{W}$ and dips sceeply $\mathrm{N}$; concains considerable galena and smaller amounts of pyr1te, chalcopyrite, sphalerite, and tetrahedrite; explored by a 45-ft. adit and a short crosscut. A breccia zone contalns quartz velnjers and pyrite-lmpregnated granodiorite with a little disseminated galena and sphalerice; strikes $\mathrm{N} 50^{\circ} \mathrm{W}$ and dips $45^{\circ} \mathrm{S}$. Elsewhere on propercy are several flssure zones in granodiorite that carry quartz velniets and a little disseminated galena and pyrite.

Byers and Sainsbury, 1956 (B 1024-F), p. 140 - Examinarion with ultraviolet lamp falled to reveal scheelite. 
Cub

Hyder district
Copper

Bradfield Canal ( $15.5,0.4$ )

$56^{\circ} 01^{\prime} \mathrm{N}, 130^{\circ} 25^{\prime} \mathrm{W}$

Sumary: Group of claims on sulfide-bearing quartz-calcice veins as much as $15 \mathrm{~cm}$ thick in banded hornfels and arglilice. Contain pyrrhotite and chalcopyrite. Active claims in 1973.

Berg and others, 1977 (B 1403), p. 40-41 - Sulfide-bearing quartz-calcite velns as much as $15 \mathrm{~cm}$ thick in banded hornfels (metagraywacke) and argillite strike $\mathrm{N} 15^{\circ}-75^{\circ} \mathrm{W}$ and dip $50^{\circ} \mathrm{NW}$ to vertical; contain pyrrhotite and chalcopyrite. Staked 1969-70.

p. 70 -- Claims active in fall of 1973.

p. 72-73 -- One of 3 groups of claims in Banded Mtn. area that were active in 1973. 
Daly-Alaska

Ryder district

$M F-418,10 \mathrm{C} .23$
Copper, Gold, Lead, Silver, Zinc

Bradfield Canal (19.15, 0.7)

$56^{\circ} 02^{\prime} \mathrm{N}, 130^{\circ} 03^{\prime} \mathrm{W}$

Sumary: Replacement deposirs in shear zones in siliclfied and pyritized greenstone and a porphyry dike related to Texas Creek batholith. Quartz-calcite and sulfide veins contaln pyrfce, pyrrhotite, sphal erite, galena, tecrahedrite, chalcopyrlte, and arsenopyrite. Considerable sliver and some gold; carefully selected samples contained as much as $500 \mathrm{oz}$. a ton silver, probably in blobs of tetrahedrite in spialerite. A little natlve silver was found in one of the workings. Developed by several hundred feet of underground workings and many open cuts. Work was between about 1915 and 1925; a little ore may have been mined. Includes references to: Elevermile, New Alaska (Mining Co.). See also: Bertha, Iron, Western.

Chapin, 1916 (B 642), p. 97 -- Open pits on Elevenmile clalm expose an ironstained lode in a brecclated zone filled wich velns of quartz carrying chalcopyrtce, sphalerice and argentiferous galena; some shoots very rich.

p. $99--$ Same as on p. 97.

Mertie, 1921 (B 714), p. 142 -- Quotation frow above.

Westgate, 1922 (B 722), p. 128 -- Types of deposits are (1) disseminated replacement deposits of galena, sphalerite, and pyrtce in greenstone;

(2) disseminated and Ienticular replacement deposits of pyrrhotite with minor chalcopyrice and pyrite and very little sphalerice in greenstone.

p. 131 133 - One of the most promising prospects in district. Deposits are In sllictfied and pyritlzed greenstone into which much calcite has been introduced. Principal development is a tunnel $114 \mathrm{ft}$. long and open cuts exposing fracture zones carrylng sphalerite, galena, and pyrite with values in gold and silver and accompanied by a little chalcopyrtte; wineralized belt strikes about $N 70^{\circ} \mathrm{E}$. Deposit grades Into country rock; no well-defined walls. In second type of deposit has been but litcle work; some ore said to have been taken out of a 10-ft. tunnel.

Brooks, 1923 (B 739), p. 21 - Underground work, 1921.

Buddington, 1925 (B 773), p. 74 -- Replacement and disseminated deposits in greenstone contain pyrite, galena, sphalertte, chalcopyrite, and pyrrhotite.

p. 83-84 -- Several hundred feet of underground development and many open cuts. Mineralized shear zones contain calcite and quartz veinlets, galena, sphaler1te, pyrchotite, chalcopyrite, and pyrice. Vein material reported to average $30-40 \mathrm{oz}$, a ton silver and to carry considerable gold. Picked samples have run as high as 500 oz. a ton silver; some probably in cecrahedrite blobs in sphalerite.

Buddington, 1926 (B 783), p. 41, 53 -- Continued developpent, 1924; good ore shoots reported to have been found in crosscurs.

Moffit, 1927 (B 792), p. 30 - Exploration continued, 1925. A 1ittle native silver found. 
Daly-Alaska -- Continued

Buddington, 1929 (B 807), p. 43 44 - Deposit of same type as at B 1 ) Missouri in B.C.

p. 86-88 -- Country rock greenstone cut by quartz and feldspar porphyry dikes from Texas Creek batholith; all cut by younger granodiorite porphyry, malchice, and lamprophyre dikes. Descriptions of types of mineralization quoted from Westgate, 1922 (B 722), p. 132. Upper workings consist of an open cut and two adits (total iength about $385 \mathrm{ft}$. ) on ore shoots primarily of pyrite accompanted by smaller amounts of sphalerite, galena, tetrahedrite, chalcopyrite, pyrrhotite, and arsenopyrite; in porphyry related to Texas Creek batholith. Farther downhill open cuts on a mineralized shoot in greenstone exposed a 3-ft.-wide zone of sulfide and quartz-calcite stringers containing galena, pyrrhotite, sphalerite, chalcopyrite, pyrite, arsenopyrite, and 30-40 oz, a ton silver and some gold. Considerable underground exploration at lower workings where similar ore shoots are in greenstone; assays of selected samples reported to have run as high as $500 \mathrm{oz}$. a ton in silver; native sllver reported to have been found near a faule in one of the tunnels.

Buddington and Chapin, 1929 (B 800), p. 318 -- Formed by replacement along shear zone.

p. 327 -- Small amount of native silver present.

p. 357-358 -- Example of low-grade complex ore with local high content of gold or silver.

West and Benson, 1955 (B 1024-B), P. 31 - Data from Buddington, 1929 (B 807), p. 43 .

Byers and Sainsbury, 1956 (B 1024-F), p. 140 -- Search with ultraviolet lamp falled to find scheelite. 
Double Anchor

Byder distriet

$M F-418,10 c .8$
Copper, Gold, Lead, Silver, Zinc

Bradfield Canal (17.1, 1.3)

$56^{\circ} 04^{\prime} \mathrm{N}, 130^{\circ} 15^{\prime} \mathrm{W}$

Summary: Quartz breccia zone in graywacke and argillite contains quartz, pyrite, galena, sphalerite, and chalcopyrite; sparse pyr rhotite; average of $3.5 \mathrm{oz}$. a ton silver and $0.022 \mathrm{oz}$. a ton gold. Exploration was by a few short adits and pits. No record of production.

Buddington, 1925 (B 773), P. 91 -- 4 claims recorded in 1923.

Buddington, 1929 (B 807), p. 98-99 -- In a shear zone in banded argillite and fine-grained graywacke; seams and stringers of quartz and sulfides, including brown sphelerite, galena, pyrtte, and chalcopyrtte; sparse pyrrhot 1te; strikes about $E$ and is flat; largest mineralized shoot is about 2-1/2 ft. thick and $30 \mathrm{ft}$. long; most are less than an inch thick. Thick quartz veins nearby are only sparsely dineralized.

Berg and others, 1977 (B 3403), P. 38-39-- Quartz-breccia zones; one is subhorizontal, $37-195 \mathrm{~cm}$ thick, and exposed for $220 \mathrm{~m}$ along strike; other strikes $\mathrm{N} 70^{\circ} \mathrm{E}$ and dips $60^{\circ} \mathrm{W}$, and is exposed along strike for $50 \mathrm{~m}$. Contain pyrite, galena, sphalerite, and chalcopyrite. Deve1oped by short adits and pits. Originally staked in 1923 and restaked as Alaska State Mines Extension in 1958.

p. 76 -- Data on history of ownership.

p. 79-84 - Oxidized quartz breccla zone in graywacke and argil-

lite is fairly flat lying; contains quattz and pyrite with sporadically distributed galena, sphalerite, and chalcopyrite; zone exposed on a cliff and in short adits and pits for a distance of 90 m and over widhs of $37-107 \mathrm{~cm}$. Weighted average of analyses of samplea across a 65 -cm width $184.3 \% \mathrm{~Pb}, 1.0 \% \mathrm{Zn}, 3.5 \mathrm{oz}$. a ton $\mathrm{Ag}$, and $0.022 \mathrm{oz}$. a ton Au. Assay values of samples from other occurrences on property are generally lower. 
Edelweiss

Hyder district

$M F-418,10 c .6$
Gold, Lead, Silver

Bradfield Canal ( $16.15,0.65)$

$56^{\circ} 02^{\prime} \mathrm{N}, 130^{\circ} 21^{\prime} \mathrm{W}$

Sumary: Quartz fissure veln in rocks of Hazelton(?) Gp. contains galena and pyrite; picked sample reported to contain $1.55 \mathrm{oz}$, a ton gold and $10.2 \mathrm{oz}$. a ton silver. Little exploration and no recorded production. See also Marmot.

Buddington, 1929 (B 807), P. 101 -- Claim near Through Glacier staked in 1926. Vein reported to be 1,500-2,000 ft. above glacler and consist of quartz with galena and pyrite. Picked sample assayed $\$ 32$ [about $1.55 \mathrm{oz.}$ ] a ton $1 \mathrm{n}$ gold and 10.2 oz. a ton in silver. Map (p1. 2) shows bedrock as Jurassic(?) tuffaceous graywacke, slate, argillite, and quartzite; some limestone.

Byers and Sainsbury, 1956 (B 1024-F), p. 140 -- Search with ultraviolet lamp falled to find scheelite.

Berg and Cobb, 1967 (B 1246), p. 182 -- Reportedly on quartz vein carrying galena, pyrice, gold, and silver.

Berg and others, 1977 (8 1403), p. 40-41 -- Quartz figsure vein in rocks of Hazelton(?) Gp. contains galena and pyrtce; $1.6 \mathrm{oz}$, a ton gold and $10.2 \mathrm{oz}$. a ton silver in picked sample. Vein 0.3 m thick, strikes $\mathrm{N} 30^{\circ} \mathrm{E}$ and is vertical. Old Edelwelss prospect is now part of Marmot group.

p. 110-123 -- Most of daca sumartzed above. Grab samples did not confirm gold content reported by Buddington [above]. Originally staked in 1925; more clatws staked in 1928; restaked as part of Marmot in 1969. Explored by open cut. 
Engineer

Hyder district

$M F-418$, loc . 13
Copper, Gold, Lead, Silver, Tungsten

Bradfield Canal (17.35, 1.0)

$56^{\circ} 03^{\prime} \mathrm{N}, 130^{\circ} 13^{\prime} \mathrm{W}$

Summary: Quartz veln 2-4 ft. thlck in granodiorite (with inclusions of older rocks) near contact with argillite and graywacke. Contains local shoots mineralized with chalcopyrite, pyrite, and galena; assays of materlal from shoots showed $0.04-0.64 \mathrm{oz}$. a ton gold, 7.6-26 oz. a ton sllver, and $11.3 \%-55.3 \%$ lead; rare grains of scheellte. Explored by $30-f t$ adit and several open cuts.

Buddington, 1929 (B 807), p. 109-110 - In Texas Creek Granodiorite near contact with argillite and graywacke; blocks of sedimentary rock to granodiortte. Vein strikes $\mathrm{N} 30^{\circ}-40^{\circ} \mathrm{W}$, dips $60^{\circ}-75^{\circ} \mathrm{NE}$, and is from 1 to $4-1 / 2 \mathrm{ft}$. Wide (generally $2-4 \mathrm{ft}$. ) and conslsts of quartz with local shoots moderately to heavily mineralized with sulfides (chalcopyrite, pyrice, and galena) and rare grains of scheelice. Explored by an adit $30 \mathrm{ft}$. long and several open cuts. Assays of 7 specimens from minerallzed shoots showed $0.04-0.64 \mathrm{oz}$. gold a ton, $7.6-26 \mathrm{oz}$. stlver a ton, and $11.3 \%-55.3 \%$ lead.

Byers and Sainsbury, 1956 (B 1024-F), P. 127 -- Reference to above. p. 140 - Rare grains of scheelite. 
Evening Star

Hyder district

MF-418, 1oc. 16 lead

Bradfield Canal (17.85, 1.5$)$ $56^{\circ} 05^{\prime} \mathrm{N}, 130^{\circ} 10^{\prime} \mathrm{W}$

Sumary: Stringer of galena in granodiorite. Explored by a 10-ft. adit. No data on possible silver conteat. Includes references to Morning Star.

Buddington, 1925 (B 773), p. 90 -- Evealng Star and Morning Star claims staked in 1923. Small open cut shows zone of shatrered granodiortte with striggers of galena and $a$ quartz stringer as much as $9 \mathrm{in.} \mathrm{wide.}$

Buddington, 1929 (B 807), p. 94 - 20-te. adit driven along a natrow stringer of steel galena that strlkes $\mathrm{N} 15^{\circ} \mathrm{W}$ in granodiorite. Parallel quartz vein about $100 \mathrm{ft}$. up mountain side. 
Fish Creek

Hyder district

$M F-418,10 c .26$
Copper, Gold, Lead, Silver, Zinc

Bradfleld Canal ( $19.05,0.3)$

$56^{\circ} 00^{\prime} \mathrm{N}, 130^{\circ} 03^{\prime} \mathrm{W}$

Sumary: Most of propercy in Ketchikan quad. Some or all of Olympia Excension claim later became last Chance claim; daca on Olympia Extension are sumarlzed here; those specifically on last Chance are summarized on last Chance sheet. On Sumblt clatm a body of pyrrhocite in pyritiferous greenstone carrles a little pyrite, arsenopyrite, chalcopyrite, quartz, $0.36 \mathrm{oz}$. a con gold, and $4 \mathrm{oz}$. a ton silver; shaft sunk $10 \mathrm{ft}$. In pyrthotite did not reach base of body. On Olympia Extension quartz fissure veln as much as $10 \mathrm{ft}$. thick in granodiortte contalns about $5 \%$ disseminated sulfides and stringers of solid sulfides in tich ore shoots; sulfides include galena, tetrahedrite rich in silver, chalcopyrite, and arsenopyrite. About $800 \mathrm{ft}$. of underground workings; shlpments of selected ore ran about $\$ 90$ a ton; swount of total production not known. Assays of samples taken across vein contalned as much as $1.42 \mathrm{oz}$. a ton gold, $94.8 \mathrm{oz}$, a ton silver, $14.5 \%$ lead, and $2 \%$ copper. See also: Flsh Creek (Ketchikan quad.), Last Chance.

Chapin, 1916 (8 642), p. 98-99 -- Fissure vein near head of Skookum Cr. $320-f t$. adlt and several crosscurs and inclines opened a fissure vein carrying tetrahedrite, chalcopyrite, galena, sphalerice and pyrite in blebs and veinlets in quartz; richest (In sllver) ore in veinlets of tetredrite and gajena; some mined and sorted for shipment. Country rock is porphyry and schistose tuff. Vein from is in. to at least 3 ft. wide; cur off by fault $300 \mathrm{ft}$. from adit mouth. [Thls property is probably part of Fish Creek and may be in Ketchlkan quad.]. Free gold reported nearby.

Mertie, 1921 (B 714), p. 142 -- Quotation from above.

Westgate, 1922 (B 722), p. 128 -- Two types of deposits: (1) Disseminated replacement deposits of pyrrhotite with minor chalcopyrite and pyrite and very lictle sphalerite in greenstone; (2) quartz fissure veins carrying pyrite, galena, sphalerite, and locally tetrahedrite and chalcopyrite in granicle rocks.

p. 131 - PromIsing prospects; considerable underground work; a little ore has been shipped. [Probably all in Ketchikan quad.].

p. 134-138 -- Bedrock of eastern part of property is greenstone; that to west is grantic. Several hundred feet of work1ags on claims in Ketchikan quad. Assays of ore run as high as $1.60 \mathrm{oz}$. a ton gold and $706.67 \mathrm{oz}$. a con silver. Only work on parc of property certainly in Bradfleld Canal quad. was on Summit clalo, where a body of pyrrhotite in pyrityferous greenstone carries a little pyrite, arsenopyr 1te, chalcopyrlte, and quartz; shaft sunk $10 \mathrm{ft}$. without reaching boctor of pyrrhotite body; samples contained $0.36 \mathrm{oz}$. a ton gold, 4 oz. a ton silver, and $2 \%$ copper.

Brooks, 2923 (B 739), p. 21 -- Silver-lead ore carrying gold and copper was shlpped, 1921. 10-15 men worked from June to end of year. 
Fish Creek -- Continued

Buddington, 1925 ( $B$ 773), p. 77-78 - Metallized quarcz fissure vein in quartz-hornblende diorite in Olympla Fraction claim exposed by trenches for a strike length of about $300 \mathrm{ft}$.; strikes about $\mathrm{N} 60^{\circ} \mathrm{W}$ and dips $50^{\circ} \mathrm{NE}$; tapers off at each end. In one trench is 4-6 ft. wide and contalns about $5 \%$ sulfides in rich ore shoots; rest of vein is mainly quartz with some calcite. Sulfides include galena, terrahedrice, chalcopyrite, sphalerite, and arsenopyrite; tetrahedrite rich in s1lver. 40 cons of selected ore from trench reported to run about $\$ 90$ a ton. About $800 \mathrm{EC}$. of underground workings; vein $2-5 \mathrm{ft}$. wide; contalns fragments of wall rock; 55 tons of sorted ore ran about $\$ 90$ a ton.

Buddington, 1926 (B 783), p. 41-42 - Reported that new tunnel will be started. [May be in Ketchikan quad.].

Buddington, 1929 (B 807), p. 43 -- Example of quartz fissure veins of lead stlver-gold type on propercy; sulfides occur as ore shoots.

p. 68-71 -- Most of work has been on part of property in Retchlkan quad. On Olympia Extension clalm [In Bradfleld Canal quad.] mineralized quattz vein as much as $10 \mathrm{ft}$. (average about $3 \mathrm{ft}$.) wide strikes $\mathrm{N} 60^{\circ} \mathrm{W}$, dips $40^{\circ}-50^{\circ} \mathrm{NE}$, and has been traced for $600 \mathrm{ft}$. In prospect pits and trenches; In Texas Creek Granodlorite; walls slickenstded. Vein cut by lamprophyse dike. Vein as exposed in one trench contains about $5 \%$ or more disseminated sulfides and stringers of solid sulfides that constituce ore shoots. Sulfides include galena, tetrahedrite, chalcopyrite, pyrite, and sphalerite. Crosscut adit and underground workings on veln are more than $265 \mathrm{ft}$. long. A shipment of 64 tons of sorted ore sent to Tacoma smelter is reported to have averaged $\$ 90$ a ton. Assays of samples taken across veln ran trace to $1.42 \mathrm{oz}$. a con gold, 3.0-94.8 oz. a tan silver, $2.5 \%-14.5 \%$ lead, and trace co $2.0 \%$ copper. Data on Sumn1t cladm quoted from Westgate, 1922 (B 722), p. $137-138$.

Buddington and Chapin, 1929 (B 800), p. 317 -- Example of fissure veins.

p. 324 - Tetrahedrite present locally in considerable amounts.

p. 327 - Ore rich in tetrahedrite reported to carry as much as $700 \mathrm{oz}$. a ton silver.

p. 358 -- Example of quartz fyssure veins.

Bain, 1946 (IC 7379), P. 42 - Moderate percentages of lead in this and other deposits in district.

West and Benson, 1955 (B 1024-B), p. 30 -- Data from Buddington, 1929 (B 807), D. 43.

Byers and Salnsbury, 1956 (B 1024-F), p, 138 -- Applicable only to part of property in Ketchikan quad.; scheelite present.

Berg and Cobb, 1967 (B 1246), p. 147 - Has been production.

Lovering, 1972 ( $(710)$, p. 90 -- Reference to Westgate, 1922 (B 722), p. $123,133,137-138$. 
Fitzgerald

Hyder district
Lead (?), Silver(?)

Bradfield Canal(?)

SE $1 / 4$ SE $1 / 4$ SE $1 / 4$ quad.(?)

Sumary: Discovery reported, 1921. No other daca; may be in Kecchikan quad.

Brooks, 1923 (B 739), p. 21 -- Discovery reported, 1921. 
Galena

Hyder district
Copper, Lead, Molybdenum, Silver, Zinc

Bradfleld Canal ( $16.35,0.7)$

$56^{\circ} 02^{\prime} \mathrm{N}, 130^{\circ} 20^{\prime} \mathrm{W}$

Sumary: Cuartz stringers in several fracture systems in hornfels contain pyrite, galena, molybdentte, sphalerite, and chalcopyrite; silver content as high as 8.7 oz. a ton. Now part of Marmot group. See also Marmot.

Berg and others, 2977 (B 1403), P. 40-41 -- Quartz stringers 1n several fracture systems in hornfels of Hazelcon(?) Gp. strike $N 15^{\circ}$ E and dip $50^{\circ}-60^{\circ} \mathrm{E}$. Contain pyrite, galena, sphalerite, molybdentte, and chalcopyrice. Originally staked in 1969; now part of Marwot group. p. 112-114 -- Fractures wit.) several different orientations in an exposed area of hornfels about 180 m long contain quartz seams and veinlets contalning small amounts of unevenly distributed sulfides, particularly at fracture intersections; sulfides include fyrite, galena, molybdenite, sphalerite, and chalcopyrite. Composite samples ran 8.7 oz a ton silver, $0.05 \%$ molybdenum, $0.65 \% 1$ ead, and $0.20 \%$ $z i \Delta c$, and $0.03 \%$ copper. 
Glacier

Ryder district

$M F-418,10 c, 5$
Copper, Gold, Lead, Molybdenum(?), Silver

Bradfleld Canal (15.7, 0.9)

$56^{\circ} 02^{\prime} \mathrm{N}, 130^{\circ} 27^{\prime} \mathrm{W}$

Sumnary: Quartz veins as much as a foot wide occupy cross fissures in graywacke with some andesite tuff and breccia; cut by lamprophyre dike. Veins contain pyrite, small amounts of pyrrhorite and chalcopy rite, and rarely galena. Assays showed $0.04 \mathrm{oz}$. gold and $6 \mathrm{oz}$. silver a ton and $3 \%$ copper. Could not be found during recent investigations; sald to have been explored by a short tunnel and some surface strlpping. Quartz float found nearby contains pyrite, chalcopyrite, and molybdenite; may have come Erom Glacier or similar veins.

Buddington, 1929 (B 807), p. 120-121 -- Quartz veins up to a foot in width occupy cross flsaures in graywacke (with some andestte tuff and breccia); veins cut by a lamprophyre dike. Veins contain pyrite and small amounts of pyrrhotite and chalcopyrite and rarely galena. Developed by an 8-ft. tunnel and some surface stripping. Assays show a little gold, $6 \mathrm{oz}$. a ton silver, and $3 \%$ copper.

Wedow and others, 1952 (OF 51), p. 57 - Quartz veins from 2 in. to about a foot thick contain much pyrite and small amounts of pyrthotite, chalcopyrite, and galena.

Berg and Cobb, 1967 (B 1246), p. 182 -- Thin quartz veins in graywacke contain abundant pyr1te, small amounes of pyrrhotite and chalcopyrite, and sparse galena; assays showed $\$ 0.80$ in gold and $6 \mathrm{oz}$. of sllver per ton and $3 \%$ copper; 1 tttle work was done.

Berg and others, 1977 (B 1304), p. 40-41, 114-116 - Could not be found; data from Buddington, 1929 (B 807). Pleces of float quartz with pyrite, chalcopyrite, and molybdenite may have come from these or similar veins. 
Goat

Ryder district
Copper, Gold, Sllver

Bradfield Canal (15.5, 0.4) $56^{\circ} 01^{\prime} \mathrm{N}, 130^{\circ} 25^{\prime} \mathrm{W}$

Sumary: Quartz-calcite veins in hornfelsed graywacke contain abundant pyrrhotice, rraces of chalcopyrite, and very minor amounts of gold and silver.

Berg and others, 1977 (B 1403), p. 40-41 -- Sulfide-bearing quartz-calcite veins as much as $15 \mathrm{~cm}$ thick in banded hornfels (metagraywacke) and argilite $5 \tau r i k e ~ N 15^{\circ}-75^{\circ} \mathrm{W}$ and dip $50^{\circ} \mathrm{NW}$ to vertical; contain pyrhotite and chalcopyrite. Staked 1969-70.

p. 70 - Clatos active in fall of 1973.

p. 72-73 - One of 3 groups of claims in Banded Mtn. area that were active in 1973.

p. $114-115$ - 2 claims gtaked in 1969 on sulfide-beariog quartzcalcite veins in slightly pyrrhotitic, hornfelsic graywacke. Veins locally contaln abundant pyrrhotite, traces of chalcopyrite, and very minor amounts of gold (no more than $0.8 \mathrm{ppm}$ ) and sliver (no more than $3 \mathrm{ppm}$ ). Vetns vary widely in width and or lentation. Geochemical sample from area contained $15 \mathrm{ppm}(0.4 \mathrm{oz}$. a ton) silver. 
Gold Cliff Premter

Hyder discrlct

$M F-418,10 \mathrm{C} .21$
Copper, Gold, Lead, Silver, IIrc

Bradfield Canal (19.15, 1.05)

$56^{\circ} 03^{\prime} \mathrm{N}, 130^{\circ} 03^{\prime} \mathrm{W}$

Summary: Shear zone in tuffaceous rock mineralized with pyrite, quartz, and calcite; carrles as much as 1 oz. a ton gold and $3-4$ oz. a con sliver. Stali stringers elsewhere on property carry galena, sphaler1te, chalcopyrite, tetrahedrite, and pyrrhorlte. Country rock is quartzite, tuff, and slate cut by porphyry dikes of 2 ages.

Buddington, 1929 (B 807), D. 90 -- Country rock is quartzite, tuff, and Intercalated slate cut by porphyriclc granodiorite dikes of 2 ages. Quartzite locally intensely fractured and pyritized; open cut exposes a shear zone in cuffaceous rock mineralized with pyrite in a band 2-1/2 ft. wide and carrying as much as $1 \mathrm{oz}$. a con gold and $3-4 \mathrm{oz}$. a con silver; calclte and quartz gangue. Two narrow stringers elsewhere on propercy carry galena, sphalerite, chalcopyrite, terrahedrite, and pyrrhotite. 
Greenpoint

Ryder district

$M F-418$, IOC. 7
Copper, Lead, Molybdenum, Silver

Bradfield Canal $(16.5,0.6)$

$56^{\circ} 01^{\prime} \mathrm{N}, 130^{\circ} 19^{\prime} \mathrm{W}$

Sumary: Quartz-calc1te veinlets not wore than $15 \mathrm{~cm}$ thick in a fracture zone in hornfels contain pyrite and small amounts of galena and molybdenite and traces of chalcopyrite; as much as 30 ppm silver in samples of veinlets. Veinlets too small and too lean to mine Individually. Explored by 2 small excavations. See also Heckla; covers some or all of the same ground.

Bain, 1946 (IC 7379), p. 42 -- Moderate percentages of lead in this and other deposits in district. [May refer to Swennings Greenpoint.]

Berg and others, 1977 (B 1403), p. 40-41 -- Sulfide-bearing quartz-calcite veinlets $1-15 \mathrm{~cm}$ thick in hornfels of Hazelton(?) Gp. contain pyrite, galena, molybdeaite, and chalcopyrite; explored by small pit and open cut .'

p. 72 -- Has been active since 1970; now abandoned.

p. 93-96 -- Quartz-calcite veinlets occupy a north-trending fracture zone that dips steeply westward; contains up to $5 \%$ pyrite and small amounts of galena and molybdenite; traces of chalcopyrite. Veins are too small and lean to be mined individually. Samples of veinlets contalned as much as 30 ppo silver. 
Heckla

Hyder district $\mathrm{MF}-418$, loc, 7
Copper, Gold, Lead, Molybdenum, Silver, Zinc

Bradfleld Canal (16.35, 0.4) $56^{\circ} 01^{\prime} \mathrm{N}, 130^{\circ} 20^{\prime} \mathrm{W}$

Sumary: Quartz figsure velns in hornfelsed graywacke of Hazelton(?) Gp. are from 18 to $116 \mathrm{~cm}$ thick and contalo pyrite, galena, sphalerite, pyrthotite, molybdenite, chalcopyrite, digenite, covellite, and malachice. One ton of ore was sledged out over glacier in 1925. Picked sample contained $0.08 \mathrm{oz}$. gold and $54.3 \mathrm{oz}$. silver a ton and $21.6 \%$ lead, $32.1 \%$ zinc, and $4.1 \%$ copper. Includes reference (Mofflt, 1927) to Humel, Blasher \& Moss. See also Greenpoint.

Mofe1t, 1927 (B 792), p. 30 - Test shipment of one ton of complex silverlead-zinc-copper ore made in 1925 by tumel. Blasher \& Moss. (On basis of statement in Buddington, 1929 (B 807), D. 102, the above must apply to Heckla prospect.]

Buddington, 1929 ( $B$ 807), p. 101-102 -- 5 clalns staked in 1925. Vein reporced to be in graywacke and exposed for a distance of $75 \mathrm{ft}$. A ton of ore broken frow outcrop was sledged out. Ore consists of galena, pyrrhotice, sphalerite, and chalcopyrite. Picked sample ylelded $\$ 1.60$ ln gold and $54.3 \mathrm{oz}$. silver a ton, $21.6 \%$ lead, $32.1 \% \mathrm{zlnc}$, and $4.1 \%$ copper.

Berg and Cobb, 1967 (B 1246), p. 147 -- Some ore has been shipped.

Berg and others, 1977 (B 1403), P. 37 -- Has been 1-ton test shipment. p. 40-41 - Quartz fissure veins in graywacke of Hazelton(?) Gp. strike $\mathrm{N} 0^{\circ}-30^{\circ} \mathrm{E}$ and dip $43^{\circ}-80^{\circ} \mathrm{E}$; contaln galena, pyrite, sphaler1te, chalcopyr1te, and molybdenite; reported values of $0.08 \mathrm{oz}$. a ton gold and 54.3 oz. a con silver, $21.6 \%$ lead, $32.1 \%$ zinc, and $4.1 \%$ copper (plcked sample). Onerton test shipment of ore broken from surface of ouccrop in 1925. Prospect is now part of Greenpoint group of clatms (staked 1970).

p. 70 - Was a one-ton test shipment.

p. 72 - One ton of ore was sledged over glacier in 1925.

p. 96-100 - Has been some recent exploration by ground geophysical methods and shallow drilling. Veins are 18-116 ca rhick; Heckla vein exposed for strike length of about $30 \mathrm{~m}$. Sulfide-bearing quartz veins in hornfelsed metasedimentary rocks of Hazelton(?) GP. that are cut by dloricle, andesitic, and quartz monzonite dikes; Hyder Quartz Monzondte crops out about 200 m to east. Veins contain quartz, pyrite, galena, sphaler1te, pyrrhot1te, molybdenite, chalcopyrite, digenite, covellite, and malachite. Gold values low (up to 0.23 oz. a ton) and spotty. Sllver from 0.09 to $20.4 \mathrm{oz}$. a ton; most samples no more chan $0.9 \mathrm{oz}$, a ton. 
Hobo

Copper, Gold, Lead, Silver, Zinc

Hyder district

Bradfield Canal (19.15, 0.7)

$M F-418$, loc. 23

$56^{\circ} 02^{\prime} \mathrm{N}, 130^{\circ} 03^{\prime} \mathrm{W}$

Summary: Veins or veinlike replacement deposits of sulfides, and quartz veins in fissures in greenstone carry pyrite, pyrrhotite, sphalerite, chalcopyrite, galena, and arsenopyrite. Generally small and variable amounts of gold and silver; sulfides in one vein carry from about 0.2 to 0.58 oz. a ton gold. Explored by opea cuts.

Buddington, 1929 (B 807), P. 43 -- Example of disseminated and lenticular replacement type of deposit.

p. 84-85 -- Open cuts in minerallzed greenstone expose veins or veinlike replacement deposits of sulfides, malaly pyrite, pyrrhotite, and sphalerite with smaller amounts of chalcopyrite, galena, and argenopyrite; some gold and silver present, but amounts generally small and variable. Another vein in greenstone contains pyrite, pyrrhotite, and a little arsenopyrite in quartz gangue; sulfides carry $\$ 4-\$ 12$ [about $0.2-0.58 \mathrm{oz}$.$] a ton gold. Nearby quartz veins in a$ fissured zone in greenstone carry pyrite, galena, and sphalerite.

West and Benson, 1955 (B 1024-B), p. 31 -- Data Erom Buddington, 1929 (B 807), p. 43 . 
Homestake

Hyder districe

$M F-418,10 c .16$
Copper, Gold, Lead, Silver, Zinc

Bradfleld Canal (17.85, 1.5$)$

$56^{\circ} 05^{\prime} \mathrm{N}, 130^{\circ} 10^{\prime} \mathrm{W}$

Sumary: Quartz fissure vein in granodiortte 18 4-5 fr. thick and contains conslderable steel galena, some chalcopyrite and pyrite, and rraces of sphalerite. Galena is argentiferous. Test shipment in 1925 of $9-1 / 2$ tons of sorted ore contained $50 \% 1$ ead, $0.7 \%$ $z$ lac, $22.87 \mathrm{oz}$. a ton silver, and $0.29 \mathrm{oz}$. a ton gold. Littile if any activity stnce about 1925 .

Buddington, 1925 (B 773), p. 88-89 - Quartz vein 4-5 ft. Wlde has been traced for about $250 \mathrm{ft}$; northern part contalns considerable steel galena, some chalcopyrite and pyrite, and traces of sphalerice; galena is argentiferous: assays of samples taken across part or all of vein carry as much as $5.8 \mathrm{oz}$. silver and $0.26 \mathrm{oz}$. gold a ton. Has been very little work on prospect.

Buddington, 1926 (B 783), p. 53 -- Crosscut reported to have cut vein 35 ft. below outcrop, 1924 .

Moffit, 1927 (B 792), p. 30 -- Test shipment of 10 tons of lead ore with some sllver and gold made in 1925 to Selby smelter.

Buddington, 1929 (B 807), p. 43 - Example of lead-silver-gold fissurevein type of deposit.

p. 94-95 -- Most of data the same as in Buddington, 1925 (8 773), p. 88-89, Country rock is Texas Creek Granodior1te. Vein strikes about $N 15^{\circ} \mathrm{E}$ and dips $45^{\circ} \mathrm{E}$. Test shipment of $9-2 / 2$ tons of sorted ore sent to Selby smelter in 1925 returned $\$ 83.72$ a ton after all charges; assay was $50 \%$ lead, $0.7 \%$ zinc, $22.87 \mathrm{oz}$. a con silver, and $0.290 z$. a ton gold.

Buddington and Chapin, 1929 (B 800), p. 317 -- Example of fissure veins. p. 320 -- So-called steel galena regembles augen gneiss with eyes of granulated pyrite in flow-banded galena; deposit subjected to intense stresses since formation.

p. 358 -- Example of quarcz fissure veins.

West and Benson, 1955 (B 1024-B), p. 30 -- Data from Buddington, 1929 (B 807), D. 30 .

Berg and Cobb, 1967 (B 1246), p. 147 -- Some ore has been shipped. 
Hyder district

Bradfield Canal $(17.4,1.4)$

$M F-418,10 C .14$

Sumary: Sulfides in shear zone in argillite and slate include sphalerite, galena, pyrite, chalcopyrite, and a little tetrahedrice. No data an precious metal content of deposit as a whole; a sample of sphalerite concained a little gold and $22.78 \mathrm{oz}$. a ton silver.

Buddington, 1929 (B 807), P. 48 -- Nearly pure sample of sphalerite contalned 0.02 oz. a ton gold and $22.78 \mathrm{oz}$. a ton silver.

p. 98 -- Shear zone in argilizte and slate contalns stringers of sulfides and quartz; zone is at least $2 \mathrm{ft}$. Wide and has a maximum of 6 in. of solid sulfides along hanging wall. Sulfides include sphalerite, galena, pyrite, chalcopyrite, and a ltttle tetrahedrite. Shear zone strikes $N 50^{\circ} \mathrm{E}$ and dips $35^{\circ} \mathrm{W}$. Very little exploratory work has been done. 
Humoel Canyon

Hyder district
Silver(?)

Bradfield Canal (16.8, 1.0)

$56^{\circ} 03^{\prime} \mathrm{N}, 130^{\circ} 17^{\prime} \mathrm{W}$

Sumary: Adit driven 3.4 m to cut a pyritic silicified zone in hornfels. Samples contained negliglble amounts of copper, lead, zinc, molybdenum, and silver; no gold.

Berg and others, 1977 (B 1403), p. 40-41 - Pyritic silicified zone in banded hornfels of Hazelton(?) Go. contains pyrite. Explored by a 3.4-m adit.

p. 86-87, 92 -- Adit driven 3.4 m to crosscut a pyritic silicified zone $18-30 \mathrm{~cm}$ wide and slightly pyritlc hornfels wall rock. Samples cut across silicified zone and in wall of adit contained negligible amounts of copper, lead, zinc, molybdenum, and silver; no gold. 
Hyder Lead (Mines, Inc.)

Byder district

MF-418, 10c. 10
Copper, Gold, Lead, Molybdenum, Silver, Zinc; Barite

Bradfield Canal (17.05, 0.95) $56^{\circ} 03^{\prime} \mathrm{N}, 130^{\circ} 15^{\prime} \mathrm{W}$

Summary: Quartz fissure velns in quartz diorite of Texas Creek batholith and overlying graywacke and tuff contain some or all of the Following sulfides: galena, pyrtce, chalcopyrite, sphalerite, pyrthotite, and tetrahedrite; molybdenite in one vein. Gangue minerals include quartz, barlte, calcite, and chlorite as well as rock fragments. Assays of samples showed as much as $16.9 \mathrm{oz}$. a ton silver and $0.18 \mathrm{oz}$. a ton gold. Veins in quartz diorite are generally leaner in metallic minerals than those in roof rocks. Exploration by surface excavations; no record of production. Includes references to: Comstock, Fortuna, Hyder Lead Mining Co., Jackson * Humel, Texas (Creek) Comstack.

Buddington, 1925 (B 773), P. 74 -- Quartz flssure velns In granodiorite contain pyrite, galena, and chalcopyrite.

p. 91-93 -- Quartz fissure velns in granodiorite and metamorphosed grayracke and tuff that form top of ridge contain galena, pyrite, and chalcopyrite; generally strike NW and dip steeply NE. Andesite porphyry and aplite dikes cut both granodiorite and metamorphic rocks. Veins as much as $11 \mathrm{ft}$. wide (most less than that). One 2-in. vein in granodiorite contalns molybdenlte. Assays of samples showed 3.6$16.9 \mathrm{oz}$. Silver and trace to $0.18 \mathrm{oz}$. gold per ton and as wuch as $0.61 \%$ copper, $72.8 \%$ lead, and $2.6 \%$ inc (some of samples picked rather than representative). Called Texas Creek Comstock in this report.

Budd1agton, 1929 (B 807), p. 43 -- Example of quartz-fissure-vein leadsilver-gold type of deposit.

p. 102-108 - Veins are in quartz diorite of the Texas Creek batholith and in the graywacke and tuff of the roof of the batholith. Veins in quartz diorice are generally leaner in metallic minerals than those in overlying bedded rocks. Veins are generally quartz veins carrying varying amounts of some of all of the following sulfides: galena, pyrite, chalcopyrite, sphalerite, pyrrhotice, and tetrahedrite. Gangue minerals include quartz, barlte, calctte, and chlorite as well as rock fragments. Exploration has been by many surface cuts and strippings. Meny detalled descriptlons of Individual veins and exposures. Free gold was found in a plece of float of unknown origin. Buddington and Chapin, 1929 (B B00), p. 317 -- Example of fissure veins. Smith, 1932 (B 824), p. 17 - Work, 1929.

Smith, 1933 (B 844-A), p. 17 -- Prospecting, 1931.

Bain, 1946 (IC 7379), p. 42 -- Moderate percentages of lead in this and other properties in district.

West and Benson, 1955 (g 1024-B), p. 30 - Data from Buddington, 1929 (8 807), p. 43 .

Byers and Sainsbury, 1956 (B 1024-F), p. 140 - Search with ultraviolet lamp failed to find scheelite. 


$\begin{array}{ll}\text { Hyder Skookum } & \text { Copper } \\ \text { Hyder dLstice } & \text { Bradfield Codal }(19.25,0.4) \\ M F-4 I 8,10 c .27 & 56^{\circ} 01^{\prime} \mathrm{N}, 130^{\circ} 02^{\prime} \mathrm{W}\end{array}$

Sumary: Replacement deposit in greenstone near a porphyry dike contains pyrrhotire and a lictle chalcopyrite and arsenopyrtie.

Buddington, 1929 (B 807), P. 72 -- Breccia veins in greenstone and a porphycy dike are generally barten of sulfides; a little pyrite. A sulflde replacement mass in somewhat schistose greenstone near contact with porphyry dike contalns pyrthotite and a little chalcopyrite and arsenopyrite; some sulfides disseminated in quartz in same zone. Very litrle work done on prospect.

Byers and Salnsbury, 1956 (B $1024-F$ ), p. 140 -- Search with ultraviolet light falled to find any scheelite. 
Tbex

Hyder district

$M F-419$, loc. 16
Copper, Lead, Silver, Zinc

Bradfield Canal (17.85, 1.5)

$56^{\circ} 05^{\prime} \mathrm{N}, 130^{\circ} 10^{\prime} \mathrm{W}$

Sumary: Quartz fissure veins in granodiortte and older argillite and quartzite within $200 \mathrm{ft}$. of contact between Texas Creek batholith and older rocks. Deposits contain mainly interbanded galena and sphalerite; pyrite, chalcopyrite, and tetrahedrite also present. Picked samples high in sllver. Crosscut driven $131 \mathrm{ft}$. to undercut an orebody at depth did not find it and work was abandoned in about 1925.

Buddington, 1925 (B 773), p. 88-89 -- Veln of sulfides and quartz in argillite and quartzite cut by dikes of granite porphyry and granodiorite; sulfides mainly interbanded sphalerite and galena; pyrtte, chalcopyrite, and tetrahedrite also present; vein generally $15 \mathrm{in.}$ to $2 \mathrm{ft}$. thick, but pinches and swells; strikes $N 5^{\circ} \mathrm{E}$ and dips steeply $E$. Assays of picked specimens said to have shown high content of silver, copper, and lead.

Buddington, 1926 (B 783), p. 53-54 -- New vein located in 1924; 5 in. to 3 $\mathrm{ft}$. wide and has been traced for several hundred feet; consists of a fissure zone in granodiorite with quartz stringers; strikes about $\mathrm{N} 10^{\circ} \mathrm{W}$ and dips $\mathrm{E}$; locally broken by small-displacement faults. Ore shoots contain galena and pyrice. Crosscut driven $131 \mathrm{ft}$. to undercut ore body described in Buddlagton, 1925 (B 773), p. 88-89, did not Elnd ore body and work was abandoned.

Buddington, 1929 (B 807), P. 96-97 -- About the same data as in above 2 references. All veins within $200 \mathrm{ft}$. of contact between Texas Creek batholith and older rocks.

Buddington and Chapin, 1929 (B 800), p. 317 -- Example of Elssure veins. p. 324 -- Tetrahedrite present locally in considerable amounts. 
Iron

Hyder district

$M P-418,100 \cdot 23$
Copper, Lead, Silver, Zinc

Bradfield Canal (19.15, 0.7) $56^{\circ} 02^{\circ} \mathrm{N}, 130^{\circ} 03^{\prime} \mathrm{W}$

Summary: Shoots of sulfides (chalcopyrite, sphalerite, and galena) are rich In silver; in 1915 a con had been mined and sacked. See also Daly-West, of which Iron may have become a part.

Chapin, 1916 (B 642), p. 97 -- Open pits exposed Iron-stained lode that strikes NE and dips steeply NW. Shoots of sulfides (chalcopyrite, sphalerite, and galena) are rich in silver; a ton has been mined and sacked for shipment (1915).

Mertie, 1921 (B 714), p. 142 - Quotation from above. 
Iron Cap

Hyder district

$M F-418,10 \mathrm{C} .15$
Copper, Gold, Silver, Zinc

Bradfield Canal $(17.6,1.45)$

$56^{\circ} 04^{\prime} \mathrm{N}, 130^{\circ} 12^{\prime} \mathrm{W}$

Summary: Fissure-vein deposit in graywacke and slate about $100 \mathrm{ft}$. above contact with granodiortte. A zone about $11 \mathrm{ft}$. wide contains stringers and veins of sulfides; main vein is $2 \mathrm{ft}$. wide, is quartz calcite, and contains shoots of pyrrhotite and chalcopyrite and pockets of sphalerite; a little arsenopyrite. A gample contained $0.04 \mathrm{oz}$. a ton gold, $6.28 \mathrm{oz}$. a ton silver, and $2 \%$ copper. Has been Itttle exploration.

Buddington, 1925 ( 8 773), p. 95 -- Reported to be on a mineralized band of argillite containing chalcopyrite and pyrite; sample assayed $0.04 \mathrm{oz}$. gold and $6.28 \mathrm{oz}$. silver a ton and $2 \%$ copper.

Buddington, 1929 (B 807), p. 44 -- Example of fissure vein deposit approximately parallel to structure in slate and tuffaceous graywacke of Hazelton Gp.

P. 98 -- Open cut exposes an 11-ft. zone of fine-grained graywacke and slate containlng stringers and veins of sulfides and $a$ 2-ft. quartz-calcite vein with shoors of pyrrhotite and chalcopyrite and pockets of sphalerfte; a little arsenopyrite. About $100 \mathrm{ft}$. above contact with Texas Creek Granodiorite.

West and Benson, 1955 (B 1024-B), P. 31 -- Dats Erom Buddington, 1929 (B 807), P. 44. 
Jokex

Hyder district
Barren

Bradfield Canal (15.0,3.6) $56^{\circ} 12^{\prime} \mathrm{N}, 130^{\circ} 28^{\prime} \mathrm{W}$

Sumary: Claims scaked in 1954 on quartz-calclte fissure velndets in fine-grained schist as a molybdenum prospect. No molybdenum, copper, lead, or zinc minerals found.

Berg and others, 1977 (B 1403), p. 42 -- Quartz-calcite fissure veinlets in fine-gralned schist of Hazelton(?) Gp. cut by aplitic quartz monzonite dikes carry pyrite and molybdenice(?). Staked in 1954 as a molybdenum prospect. Intense 1ron-oxide alteration within $15 \mathrm{~cm}$ of dikes; sulfides very sparse and mainly associated with veinlets. p. 73 -- Group of claims staked for molybdenum in 1954 near international boundary within sight of Granduc mine (in B.C.); no ore bodtes or mineralization similar to Granduc found.

p. 123 - 20 clatms staked in 1954. Rusty zone in sch1st apparencly from oxidation of rock-forming minerals; no molybdenum, copper, lead, or zinc minerals observed; no samples assayed. 
Jumbo (Banded MEn.)

Hyder district
Lead, Molybdenumo

Bradfield Canal ( $16.2,0.5)$

$56^{\circ} 01^{\prime} \mathrm{N}, 130^{\circ} 21^{\prime} \mathrm{W}$

Sumary: Old prospect (first staked in 1925) that now is part of Marmot group. Quartz fissure veins in graywacke coatain pyrite, galena, and molybdenice. See also Marmot.

Buddington, 1929 (B 807), p. 101 -- 2 clalms staked 1n 1925. [Galena probably present.)

Byers and Salnsbury, 1956 (B 1024-F), p. 140 -- Examination with an ultraviolet lamp falled to disclose scheelite. (This reference may be to Jumbo (Texas $\mathrm{Cr}$, ). 1

Berg and others, 1977 (B 1403), p. 40-41 -- Quartz fissure velns 15-60 cm thick in graywacke of Hazelton(?) Gp. strike $\mathrm{N} 10^{\circ} \mathrm{E}$ and dip steeply; contalo pyrite, galena, and molybdenite. Has been recent work; now covered by Marmor group of claims.

p. 101 -- Ground now Included in Marmot group. Old Jumbo prospect could not be found with certainty; had been firgt staked in 1925 and was restaked at least 3 times. Adit sald to have been driven after Buddington's work (Buddington, 1929 (B 807), p. 101). 
Jumbo (Texas Cr.)

Hyder district

MF-418, loc. 13
Copper, Lead, Zinc

Bradfield Canal (17.35, 1.0)

$56^{\circ} 03^{\prime} \mathrm{N}, 130^{\circ} 13^{\prime} \mathrm{W}$

Summary: Graywacke in roof pendant in granodiorite contains a breccia vein along a shear zone 1 to $3-1 / 2 \mathrm{ft}$. wide. Vein consists of quartz stringers $1 \mathrm{in.}$ to $2 \mathrm{ft}$. wide that carry galena, pyrice, and chalcopyrite; some of country rock impreguated with pyrite and chalcopyrite; intersecting fissure zone carries quartz, galena, pyrite, chalcopyrite, and sphalerite.

Buddington, 1929 (B 807), P. 111 -- Country rock is graywacke roof pendant in Texas Creek batholith (granodiorite). Breccia vein along a shear zone that strikes $\mathrm{N} 30^{\circ} \mathrm{E}$ and dips $75^{\circ} \mathrm{E}$ is 1 to $3-1 / 2 \mathrm{Et}$. wide; quartz stringers are $1 \mathrm{in.}$ to $2 \mathrm{ft}$, wide and carry sulfides, Including galena, pyrite, and chalcopyrite. Some of graywacke impregnated with pyrite and a little chalcopyrite. An 1ntersecting fissure zone carrles quartz, galena, pyrtte, and a little chalcopyrite and sphalerite.

Byers and Sainsbury, 1956 (B 1024-F), p. 140 - No scheelite found with ultraviolet lamp. [This reference may refer to jumbo (Banded Mtn.).] 
Juneau

Hyder district

MF $-418,10 \mathrm{C}, 12$
Copper, Lead

Bradfield Canal $(17.5,0.5)$

$56^{\circ} 01^{\prime} \mathrm{N}, 130^{\circ} 13^{\prime} \mathrm{W}$

Summary: Quartz velns in granodiorite carry galena, pyrtte, and chalcopyrite. Little if any development.

BuddIngtoo, 1929 (B 807), P. 108-109 -- Quartz vein 3-6 ft. wide In Texas Creek Granodlorice, reportedly traced for $1,300 \mathrm{ft}$., locally has small shoots of chalcopyrite. Vein strikes $N 40^{\circ} \mathrm{W}$ and dips $50^{\circ} \mathrm{NE}$. Another vein is sald to carry galena and pyrite. 
Keno

Hyder district

ME-418, 1oc, 11
Copper, Gold, Silver, Lead, ZInc

Bradfield Canal (17.25, 0.65)

$56^{\circ} \mathrm{O} 2^{\prime} \mathrm{N}, 130^{\circ} 14^{\prime} \mathrm{W}$

Summary: Quartz fissure vein in granodiorite contains galena, pyrite, chalcopyrite, sphalerite, cetrahedrtte, and as much as $0.60 z$. a ton gold and $3 \mathrm{oz}$. a ton silver. Also disseminated pyrite and barite.

Buddington, 1925 (B 773), p. 94 -- Quartz fissure veins in granodlorlte pinch and swell; generally 2-4 ft. wlde. Contain galena and other sulfides. A specimen sample contained $0.6 \mathrm{oz}$. gold and $3 \mathrm{oz}$. silver a ton and 48\% lead; typical samples much less rich. Veins strike generally $N W$ and dip steeply NE. Wall rock contains considerable epidote, but otherwise appears unaltered. Very 11ttle work has been done on prospect.

Buddington, 1929 (B 807), p. 108 -- Adit drlven 50 ft. along a quartz vein as much as 4-1/2 (average 3-4) ft. wide in Texas Creek Granodiortte. Vein strikes $N 42^{\circ} \mathrm{W}$ and dips $70^{\circ}-80^{\circ} \mathrm{NE}$; has been traced for length of $400 \mathrm{ft}$. and difference in altitude of $300 \mathrm{ft}$. Ore shoots of solid sulfide as much as $7 \mathrm{in}$. wide consist of galena, pyrtte, chalcopyrite, sphalerite, and tetrahedrtte. Quartz also carries disseminated pyrite and locally some barite. Adit has not been driven far enough to intersect a sulfide shoot exposed ac surface. 
Lake

Hyder district

$\mathrm{MF}-418,10 \mathrm{C}, 9$
Copper, Lead

Bradfleld Canal (16.85, 1.1$)$

$56^{\circ} 03^{\circ} \mathrm{N}, 130^{\circ} 17^{\prime} \mathrm{W}$

Sumary: Quartz fissure vein about 11 in. thick in granodiorite near contact with older sedimentary rocks contains abundant galens and some pyrite along footwall; trace of chalcopyrite identified under microscope.

Buddington, 1925 (B 773), 0. 74 -- Quartz flssure velns in granodiorite contain pyrite, galena, and chalcopyrite. [A general statement.]

p. 91 - Quarcz flssure vein 11 in, wide in quartz diorite strukes $N 35^{\circ} \mathrm{W}$ and dips $60^{\circ} \mathrm{E}$. Contains galena and pyrtte along footwall. Has been no work on prospect.

Buddington, 1929 (B 807), P. 101 -- Vein in Texas Creek Quartz Diorite just below contact with older sedimentary rocks is 11 in. wide, strikes $\mathrm{N} 35^{\circ} \mathrm{W}$, and dips $60^{\circ} \mathrm{E}$. Abundant galena and less pyrite along footwall. Exposed along.a trail.

Byers and Sainsbury, 1956 (9 1024-F), p. 140 - Examination with ultravioler lamp falled to find scheelite.

Berg and others, 1977 (B 1403), D. 38-39 - Quartz Eissure vein about 30 $\mathrm{cm}$ thick in quartz diorlice of Texas Creek Granodiorite Jugt below contact with overlying Hazelton(?) Gp. Strikes $N 35^{\circ} \mathrm{W}$ and dips $60^{\circ} \mathrm{E}$. Contains galena, pyrite, and chalcopyrite.

p. 84 - Quartz vein $101 \mathrm{~cm}$ wlde exposed in open cut; In Texas Creek granodiorice just below contact with Hazelton(?) retamorphic rocks; strikes $\mathrm{N} 35^{\circ} \mathrm{W}$ and dips $65^{\circ} \mathrm{NE}$; concains vistble pyrite and galena and a trace of chalcopyrtite. 
Lakeside

Hyder district
Lead, Silver

Bradfle1d Canal (16.9, 1.1)

$56^{\circ} 03^{\prime} \mathrm{N}, 130^{\circ} 16^{\prime} \mathrm{W}$

Sumary: Quartz veins in granodiorite contain pyrite and galena; sample that may be of a boulder contains $0.4 \mathrm{oz}$. a ton silver. Little exploration. See also Morning.

Berg and others, 1977 (B 1403), p. 38-39-- Quartz veins 30 cm thick in Texas Creek Granodlortte strike $N 25^{\circ} \mathrm{W}$ and dip $65^{\circ} \mathrm{E}$; contain pyrite and galena. Explored by several pits. Staked 1n 1923; probably a relocation of Morning. Now covered by Lone Star group.

p. 72 -- Lone Star group covers parts of old Lake, Lakeside, and Blasher locations.

p. 84-87 - Probably a relocation of Morning claims; vein described by Buddington (1929, B 807, p. 101) was not found. Massive quartz that may be boulder material in overburden over granodiorite contains $280 \mathrm{ppm} \mathrm{Cu}, 4,000 \mathrm{ppm} \mathrm{Pb}, 120 \mathrm{ppm} \mathrm{Zn}$, and $15 \mathrm{ppm}(0.4 \mathrm{oz}$, a ton) $\mathrm{Ag}$. 
Last Chance

Hyder district

MF- 418 , 1oc. 26
Copper, Gold, Lead, Silver, Tungsten, Zinc

Bradfield Canal $(19.05,0.3)$

$56^{\circ} 00^{\prime} \mathrm{N}, 130^{\circ} 03^{\prime} \mathrm{W}$

Summary: About $850 \mathrm{ft}$. of underground workings and many open cuts. Quartz vein as much as 4 ft. thick traced for several hundred feet on surface and for $180 \mathrm{ft}$. underground. Carries galens, tetrahedrite, chalcopyrite, and sphalerite; sparse scheelite. According to geologic map (Byers and Sainsbury, 1956 (8 1024-F), pl. 13) country rock is Texas Creek Granodlorite. Small test shipment of ore in 1935 carrled gold and gllver. This property was originaliy part of Fish Creek property; see Fish Creek for data on Last Chance when it was part of Fish Creek.

Smith, 1937 (B 880-A), p. 18-19 -- Small test shipment of ore in 1935; carried gold, considerable silver-bearing galena, and some sulfides of other metals [which ones not specified].

Byers and Salnsbury, 1956 (B 1024-F), P. 128 - Sulfide veinlets cut barren quartz.

p. 139 -- Formerly known as Olympia Extension [part of Fish Creek]; developed by $700 \mathrm{ft}$. of tunnels on 2 levels, a $50-f t$. raise, and 2 winzes each $50 \mathrm{ft}$, deep (both now Ellled with waste). Vein traced for several hundred feet on surface in open cuts and for $180 \mathrm{ft}$. underground; as wuch $854 \mathrm{ft}$. thick; carries galena, tetrahedrite, chalcopyrite, and sphalerite; scheelite in a length of $50 \mathrm{ft}$. In one drift; $\mathrm{WO}_{3}$ content estimated at about $0.05 \%$. A few 150lated scheelite crystals in another drift; none found in surface cuts.

Berg and Cobb, 1967 (B 1246), p. 147 -- Some ore has been shipped. 
- (Leduc R.)

Hyder district
RE

Bradfleld Canal $(13.8,1.85)$

$56^{\circ} 06^{\prime} \mathrm{N}, 130^{\circ} 35^{\prime} \mathrm{W}$

Summary: Accessory allanice, sphene, and opeque minerals in a porphyritic biotite granodiorlce that may be a reheated mylonite.

Smith and others, 1977 (MF-825), sample 35012 - Accessory allanite, sphene, and opaque minerals in leucocratic porphyritic blotite granodlorite(?); possibly a reheated mylontce. 
Liberty

Hyder district

$\mathrm{MF}-418,10 \mathrm{C} .17$
Lead, Tungster

Bradfield Canal (17.9, 1.05)

$56^{\circ} 03^{\prime} \mathrm{N}, 130^{\circ} 10^{\prime} \mathrm{K}$

Sumbary: Quartz velo as wuch as $2 \mathrm{ft}$. thick in granodiorite concains local shoots of galena and rare scheelite grains. Exposed in creek bed; no exploration work. See also Stoner-Clegg-o'Rourke, where there is a Liberty claim.

Buddington, 1929 (B. 807), p. 93-94 -- Quartz veln, with local shoots of galena, in Texas Creek Granodiorite is as much as $2 \mathrm{ft}$. wide; strikes $N 50^{\circ} \mathrm{E}$ and dips $70^{\circ} \mathrm{E}$. Exposed in creek bed, has been no work.

Byers and Sainsbury, 1956 (B 1024-F), P. 140 -- Rare grains of scheelite. 
Marietta

Hyder district

$M F-418,10 c .8$
Copper, Gold, Lead, Stlver

Bradfield Canal $(17.0,1.6)$

$56^{\circ} 06^{\prime} \mathrm{N}, 130^{\circ} 16^{\prime} \mathrm{W}$

Sumbry: Searching for source of float by tunneling under glacter resulted in production of $300-400 \mathrm{oz}$. of gold and electrum during late $1930^{\prime} \mathrm{s}$ and early $1940^{\prime} \mathrm{s}$, according to local residents. Samples of nearby outcrops and of float contalned small amounes of galena, pyrrhotite, and chalcopyrite. See also Silver king; may be che same ground.

Smith, 1933 (B 844-A), p. 17 -- Some development, 1931.

Berg and others, 1977 (B 1403), p. 37-39 -- Local residents report that 300-400 oz. of electrum was produced in 1937. Area has been restaked several times.

p. 70 - 300 400 oz. of gold and electrum has been produced, according to local residents.

p. 72 - 300-400 oz. of native gold and electrum produced in late $2930^{\prime}$ 's and early $1940^{\prime} \mathrm{s}$, according to local residents.

p. 76-78 -- Mining from ice tunnels beneath glacler; driven to find lode sources of gold- and electrum-bearing float; 300-400 oz. reported to have been mined. Samples from nearby outcrops contained a little pyrthotite and traces of chalcopyrite; some argentiferous galena float. Claims lapsed in 1950 and were restaked. Marletta 19 near oló Sxlver King; way be the same property. 
Marmot

Hyder district
Copper, Gold, Lead, Molybdenum, S1lver, Zinc

Bradfield Canal (16.0-16.2, 0.5 -0.6) $56^{\circ} 01^{\prime} \mathrm{N}, 130^{\circ} 21^{\prime}-130^{\circ} 22^{\prime} \mathrm{W}$

Summary: Sulfide-bearing quartz veins as much as $45 \mathrm{~cm}$ thick and massive sulfide stringers as much as $15 \mathrm{~cm}$ thlck; country rock is hornfels, phyllite, and schist of Hazelton(?) Gp. Intruded by 2 generations of dikes. Samples contained (some in trace amounts only) pyttce, molybdenite, galena, sphalerice, and chalcopyrite; as much as $5.8 \mathrm{oz}$, a con silver, and a race of gold. Claims active in 1973; covered some or all of old Jumbo, Edelwelss, and Calena prospects. See also: Edelweiss, Galena, Jumbo (Banded Mtn.).

Berg and others, 1977 (B 1403), p. 40-41 - Sulfide-bearing quartz veins as much as $15 \mathrm{~cm}$ chick. Country rock is banded, variegated hornfels, phyllite, and fine-grained schist of Hazelton(?) Gp., andesite dikes (Texas Creek(?) Granodiorite), and aplite dikes (Hyder(?) Quartz MonzonIte). Contaln chalcopyrite, galena, pyrite, and molybdenum. Currently active, has been some stripping. Staked in 1969; covers old Edelweiss and Jumbo (Banded Mtn.) prospects.

p. 60 -- Very fine-grained molybdenite in selvages a cor or so wide at margins of quartz veins that also carry pyrite and chalcopyrite; veins parallel to composition banding in Hazelton(?) phyllite and hornfels.

p. 70,72-73 - Claims active in 1973.

p. 100-114 - 51 claims staked in 1969 cover all or parts of old Jumbo (Banded Mtn.), Edelweiss, and Galena prospects. Samples of veins and a breccla zone contained pyrite, molybdenite, galena, sphalerite, and chalcopyrtie, some in trace amounts only. Some silver values as high as $200 \mathrm{ppm}$ ( $5.8 \mathrm{oz}$. a con); highest gold value reported is $0.1 \mathrm{ppm}$. 
Monarch

Hyder district

$\mathrm{MF}-418,10 \mathrm{c} .26$
Copper, Gold, Lead, Silver, Tungsten, Zinc; Barite

Bradfieid Canal (19.05, 0.3)

$56^{\circ} 00^{\prime} \mathrm{N}, 130^{\circ} 03^{\prime} \mathrm{W}$

Sumary: Quartz veins in granodiorite contain local shoots of galena, pyrite, tetrahedrite, sphalerite, and chalcopyrite; also sparse scheelite (one smal1 vein contains an estimated $0.5 \%$ to $3.0 \% \mathrm{wO}_{3}$ ) Samples frow one vein contained as much as $1-1 / 2$ oz. a ton in gold. A specimen of tetrahedrite contained $266 \mathrm{oz}$. a ton silver. Considerable barite locally.

Buddington, 1929 (B 807), p. 74-75 -- Northwestward-striking quartz veins In Texas Creek Granodiorite contain local shoots of galena, pyrite, tetrahedrite, sphalerite, and chalcopyrite. Locally there are sparse grains of scheelite. Samples from one vein showed $\$ 20-\$ 30$ [about ] to $1-1 / 2 \mathrm{oz}$.$] a ton in gold. A specimen of tetrahedrite contalned$ 266 oz. a ton in silver. Considerable barite locally. Has been practically no developwent.

Baln, 1946 (IC 7379), P. 68 - Scheelite present.

Thorne and others, 1948 (RI 4174), p. 4 -- Buddington mentioned presence of scheelite [reference given is incorrect].

Byers and Sainsbury, 1956 (B 1024-F), p. 139 -- 30-ft. drift exposed a quartz veinlet $4 \mathrm{in}$. thick and extending along most of length of drift; estlmated to contain from $0.5 \%$ to $3.0 \% W_{3}$. Vein may be part of olympia Extension vein that crops out 1,000 fE. to SE. 
Morning

Hyder district

$M F-418,10 c, 9$
Lead

Bradfield Canal (16.95, 1.2)

$56^{\circ} 04^{\prime} \mathrm{N}, 130^{\circ} 36^{\prime} \mathrm{W}$

Sumary: Quartz vein in granodiortte is 2-4 ft. thick and contains much pyrite and sparse pockets of galena. See also Lakeside.

Buddington, 1929 (B 807), p. 101 -- Quartz vein 2-4 ft. thick in Texas Creek Granodiorite strikes $\mathrm{N} 40^{\circ} \mathrm{W}$ and dips $45^{\circ} \mathrm{NE}$. Much pyrite and sparse pockets of galena. Vein stripped for $40 \mathrm{ft}$.

Byers and Sainsbury, 1956 (B 1024-F), p. 140 - Examination with u1traviolet lamp failed to find scheelite. 
Ninety-Six

Hyder district

$\mathrm{MF}-418,10 \mathrm{c} .20$
Copper, Lead, Z1no

Bradfield Canal (18.9, 0.95$)$

$56^{\circ} 03^{\prime} \mathrm{N}, 130^{\circ} 04^{\prime} \mathrm{W}$

Summary: Breccia vein in granodiorite dike In interbedded slate and quartz1te 15 about $S$ ft. thick and contains a total of somewhat more than a foot of quartz; carries galena with smaller amounts of sphalerite, retrahedrite, pyrite, and chalcopyrite. Developed by a 63-ft. adic and open cuts. No record of production. Includes reference to Snyder.

Buddington, 1925 (B 773), P. 87 -- Snyder has prospect on a vein in a shattered zone in granodiorite porphyry that is about $3 \mathrm{ft}$. thick and strikes $N 25^{\circ} \mathrm{W}$ and $\mathrm{d} 1 \mathrm{ps} 40^{\circ} \mathrm{E}$. Vein consists of reticularing quartz veinlets and stringers with a total thickness [of quartz] of 12-14 in. and contains in places much galena, sphalerite, a little chalcopyrite, and sparse tetrahedrite. Several open cuts and strippings on small quartz veins that do not appear to be persistent as well as smail open cut on main vein.

Buddington, 1929 (B 807), P. 93 -- Breccia vein In dike of Texas Creek Granodiorite in interbedded slate and quartzite $1 s$ about $5 \mathrm{ft}$. thick, strikes about $\mathrm{N} 10^{\circ} \mathrm{W}$, and dips $40^{\circ} \mathrm{E}$; has been traced on surface for $200 \mathrm{ft}$. Galena 18 predominant sulfide, accompanted by sphalerite, tetrahedrite, pyrte, and chalcopyrite. 63-ft-adit driven to cut vein about $30 \mathrm{ft}$. below outcrop.

Byers and Sainsbury, 1956 (B IO24-F), p. 140 -- Examination with ultraviolet lamp failed to find scheelite. 
(North Bradfield R.)

Petersburg district

$M F-418$, locs. 2-4
Copper, Iron

Bradfield Canal (5.65-5.9,6.75-7.1) $56^{\circ} 23^{\prime}-56^{\circ} 24^{\prime} \mathrm{N}, 131^{\circ} 23^{\prime}-131^{\circ} 25^{\prime} \mathrm{W}$

Sumary: Il bodies of wagnetite with minor pyrrhotite and chalcopyrite in roof pendant of metamorphic rocks in quartz monzonite of Coast Range batholith. Individual bodies are 50-350 ft. Iong and 2-40 ft. thick, crudely stratiform and apparently discontinuous, and probably contain 50\%-60\% iron and $0.1 \%-0.5 \%$ copper. Very little surface alteration. Not enough data for an economic appraisal of prospect, which was discovered in 1955 and explored by surface stripping and $186 \mathrm{ft}$. of diamond-drill holes.

Mackevect and Blake, 1963 (B 1108-D) -- Magnetite deposits at NW end of a large roof pendant of gueiss, granulite, schlst, marble, and skarn in quartz monzonite of Coast Range batholith; cut by quartz diorite, aplite, and alaskite dikelike bodies; complexly folded, gross structure of pendant is an overturned syncline; pendant probably extends for many miles to SE. Skarn developed in marble units of roof pendant; in tum partially replaced by bodies essentially composed of magnetite with incerstitial pyrrhotite cut by velnlets of chalcopyrite. Ore contains subordinate amounts of hematite, hydrous iron sesquioxides, and malachite. Ore bodies are crudely stratiform and apparently discontinuous; range in strike length from 50 to $350 \mathrm{ft}$. and in thickness from 2 to $40 \mathrm{ft}$. Il ore bodies exposed. Discovered in 1955; only exploration has been some serlpping, an aeromagnetic survey, and 6 diamond-drill holes (total length $186 \mathrm{ft.}$. Most bodies probably contain $50 \%-65 \%$ fron and $0.1 \%$ $0.5 \%$ copper. Not enough data for an economic appralsal of prospect.

Berg and Cobb, 1967 (B 1246), p. 193 - Swmary of above. 
Hyder district

Eradfield Canal $(17.35,1.0)$

$M F-418,10 c .13$ $56^{\circ} 03^{\prime} \mathrm{N}, 130^{\circ} 13^{\prime} \mathrm{W}$

Sumbary: Quartz fissure vein in graywacke near contact with granodiorite contains local shoots of galena with a little pyrtte. See also Monarch, where there is another North Star claim.

Buddington, 1929 (B 807), p. 110 -- Claim on a fissure vein in graywacke about 50 yards from contact with Texas Creek Granodlorite. Vein is 1 to $2-1 / 2 \mathrm{Et}$. wide, strikes $\mathrm{N} 40^{\circ} \mathrm{W}$, and dips $70^{\circ} \mathrm{SE}$. Exposed for a length of $50 \mathrm{ft}$. Consists of quartz whth local shoots of galena and a little associated pyrite. 
Nothlger

Hyder district

MF-418, 10c. 17
Lead

Bradfield Canal (17.9, 1.05)

$56^{\circ} 03^{\prime} \mathrm{N}, 130^{\circ} 10^{\prime} \mathrm{W}$

Sumbry: Shear zone in granodiorite contains a quartz vein and many small stringers; only traces of galena and pyrite. Zone penetrated by crosscut.

Buddington, 1929 (B 807), p. 94 -- Extensively sheared zone in Texas Creek Granodiorite $20-40 \mathrm{ft}$. thick contains a quartz vein and many small stringers; main vein $2-1 / 2$ to $6 \mathrm{ft}$. thick, strikes about $N 40^{\circ} \mathrm{E}$, and dips $38^{\circ}$ E. Explored by a crosscut driven through main vein into footwall. Only a trace of galena and pyrite tn the quartz. 
Portland

Hyder district

$M F-418,100.23$
Copper, Lead, Zinc

Bradfleld Canal ( $19.15,0.7)$ $56^{\circ} 02^{\prime} \mathrm{N}, 130^{\circ} 03^{\prime} \mathrm{W}$

Summary: Quartz vein in slate is $3 \mathrm{ft}$. wide and contains sparse disseminatlons and small blebs of pyrite, galena, sphalerite, and chalcopyrite. Vein traced 500 yards by pirs and surface exposures.

Buddington, 1929 (B 807), p. 84 -- Granodiorice porphyry dike cutring greenstone and slate. Quartz vein with many inclusions of both dike rock and slate exposed by open cut. A 2-ft, quartz vein in slate strikes $N 60^{\circ} \mathrm{W}$ and dips $52^{\circ} \mathrm{S}$; explored by a 15-ft. adit; has been traced for 500 yards by pits and surface exposures. Containg sparse disseminated flne gratos of pyrite, galena, and blebs of sphalerite and a little chalcopyrite. 
Riverside (Mining \& Mlling Co.)

Hyder district

MF-418, 10c. 25
Copper, Gold, Lead, Silver, Tungsten, Zinc

Bradfleld Canal (18.9, 0.3$)$

$56^{\circ} 00^{\prime} \mathrm{N}, 130^{\circ} 04^{\prime} \mathrm{W}$

Sumary: Two main quartz velns in Texas Creek Granodiorite and one deposit (Lindeborg) in shear zone in schise incluston in granodiortte (most 1nvestigators) or zone of mylonite gneiss and ultramylonice derived from granodlorite (J. G. Smith). Lindeborg deposit is partly a mineralized quartz veln and partly the result of replacement (according to most Investigacors) of calcareous laminae in schist inclusion. Lindeborg deposit contains considerable schee1fte; the others carry only small amouncs. Other than scheeltre, the principal metallic minerals are galena, pyrite, tetrahedrite, pyrrhotice, chalcopyrite, sphalertte, and gold. Principal gangue mineral is quartz, accompanied by small amounts of calcite, arkerite, and barite. Mine operated (nor continuously) from 1925 to 1951; conslats of more than 6,000 ft. of underground workings. Explored by about 4,600 ft. of diamond-drill holes (mainly during World War II). Production was about 30,000 tons of ore that yielded abour 3,000 oz. gold, 100,000 oz. s1lver, 100,000 lbs. copper, 250,000 lbs. 1ead, 20,000 Ibs. zinc, and 3,500 units $\left(70,000\right.$ lbs.) $\mathrm{wO}_{3}$. Includes references to: Lindeborg, Riverview.

Chapin, 1916 (8 642), p. 97 -- On Riverside and Rivervlew claims welldeflaed fissure velns in crystalline schlst pinch and swell from about a foot to as much as $4 \mathrm{ft}$. in thickness; quartz carries abundant sulfides, including pyrite, chalcopyrite, and galena. Velns strlke about $\mathrm{N} 60^{\circ} \mathrm{W}$ and dip abour $60^{\circ} \mathrm{NE}$. Adit $140 \mathrm{ft}$. long on Riverside claim and one $17 \mathrm{ft}$. long on Riverview.

Mertie, 1921 (8 714), p. 141-142 -- Quotation from above.

We stgate, 1922 (B 722), p. $139-2$ tumnels driven on a quartz vein that strikes $\mathrm{N} 60^{\circ} \mathrm{W}$ and dips $60^{\circ} \mathrm{NE}$; vein $3 \mathrm{ft}$. thick in one tunnel; in sheared grantte porphyry. In one tunnel small quartz stringers parallel main vein, particularly in footwall. Sulfides include pyrite, galena, and chalcopyrice.

Brooks, 1923 (B 739), p. 21 - Underground work, 1921.

Buddington, 1925 (B 773), p. 74-75 - Quartz Eissure veins in granodLorile contain pyrtte, galena, and chalcopyrite. "Cross" vein is transittonal between velns with predominant galena and pyrtte and veins with galena associated with eetrahedrtte, chalcopyrite, and other sulfides.

p. 79-82 -- About 2,400 ft. of underground workings and many surface excavations (as of 1923). 3 fissure velns in somewhat sch1stose granodiorite belng prospected. Veins pinch and swell from a fraction of an inch to as much as $5 \mathrm{ft}$.; consist malnly of quartz (some included wallrock) with sulfides (pyrite, galena, sphalerite, chalcopyrite, and pyrrhotite) and values in gold and silver; some of ore averages $\$ 46$ a ton [1923 prices] in total metals, with some running as high as $\$ 100$ a ton. Plan to put in a 50-ton mill.

Buddington, 1926 (B 783), p. 41, 53 - Developmenc, 1924. Installation of mill warranted. 
Riverside (Mining \& Miling Co.) -- Continued

Smith, 1926 (B 783), p. 22-23 -- Ore sufficlently rich to lead owners to feel justified to put in a mill, 1924.

Moffit, 1927 (B 792), p. 30 -- New mlll operaced for at least 2 months in 1925, producing a galena concentrate carrying silver and gold.

Buddington, 1929 (B 807), p. 43 -- Example of deposits of quartz-fissure-vein lead-silver-gold type.

p. 77-81 -- Mill operated part of 1925; produced more than 109 tons of galena concentrate reported to have assayed as high as $\$ 240$ $\$ 300$ a con in lead, gold, and silver; all ore milled came from Cross veln. In 1925 there were over $5,000 \mathrm{kt}$. of underground workings.

Councry rock is Texas Creek Granodlorite with included bands of rocks of the Hazelton $\mathrm{Gp}$. now metamorphosed and recrystallized to schist or injection gneiss. Younger granodiortte dikes cut country rock; noc found in contact with veins. Malchite dikes cut both veins and country rock. I mineralized quartz veins; Ickls and Cross veins are in granodiortte and Lindeborg (or main) vein is in an included band of schist or infection gneiss. Ickls vein in Eissure in shattered, slickensided greissic granodioritic rock; consists of quartz with local concentrations of pyrite, galena, and rare sphalertte; assays as high as $\$ 20$ a ton in gold, sllver, and lead reported. Cross vein averages 2 or more ft. thick; mainly quartz whth shoors of sulfides (malnly galena and pyrite with chalcopyrite, sphalerite, tetrahedrite, and pyrrhotite) that carry considerable gold and silver; barite In gangue; some of ore mined ran as high as $\$ 100$ a ton in gold, silver, and lead. Lindeborg vein 1n shear zone in inclusion of schist; made up of an average of 3 ft. of quartz wich local concentrations of pyrite, galena, a little chalcopyrite, and sparse sphalerite; some ore has been mined; vein traced in workings and on surface for $1,800 \mathrm{ft}$.

Buddington and Chapin, 1929 (B 800), p. 317 - Example of fissure velas.

p. 324 -- Tetrahedrite present.

p. 330 -- Shoot of scheelite has been found in a veln.

p. 347 - Concentraces from mine in 1926 reported to have contained $1.4 \mathrm{oz}$. a ton gold, $32 \mathrm{oz}$, a ton sllver, and $60 \%$ lead.

Sw1th, 1929 (B 797), p. 37 -- Mining, 1926.

Smith, $1930^{\circ}$ (B 810), p. 12 - Several hundred tons of concentrates sent to smelter, 1927; gold also recovered in mill at mine.

p. 46 -- Some copper derived from concentrates, 1927.

p. 49 -- Largest stluer producer of area; gold and lead also recovered from concentrates.

p. 51 - Second greatest lead producer In Alaska (Alaska-Juneau [Juneau quad.] was first), 1927.

Smith, 1930 (B 813), p. 15 - Mine 1dle, 1928.

Sm1th, 1932 (8 824), p. 17 -- Prospecting and development, 1929; may have been a test shipment.

Smith, 1934 (B 857-A), p. 16 -- Steps taken to reopen mine; did not happen in 1932.

Smith, 1934 (B $864-A$ ), p. 16 - Mine inactive, 1933. 
Riverside (Mining \& Mlling Co.) - Continued

Smith, 1942 (B 933-B), p. 94 - Mine reopened as a source of tungsten; mainly sampling and preparatory work, 1940. Considerable ore mined and stockpiled. Beneficiation plant planned to process about 50 tons a day of ore running $2 \%$ metallic tungsten.

Bain, 1946 (IC 7379), p. 68-69 - - Tungsten production began in 1940. Praduction in 1944 was "46 tons of 21.23 percent concentrace plus secondaries treated at Salt Lake City."

Thorne and others, 1948 (RI 4174), p. 4-5 -- Buddington reported scheelite [reference incorrect]. USBM had exploration and development program, $1942-43$.

p. 36-44 -- Mining, 1925 and 1928. In 19413,400 tons of ore was milled; produced 30 tons of scheelite concentrate running $44 \% \mathrm{WO}_{3}$ and 49 tons of galena concentrate running $68 \%$ lead, $31 \mathrm{oz}$. a ton silver, and $1.1 \mathrm{oz}$. a ton gold. In $1942 \mathrm{mill}$ produced 36.6 tons of $10.15 \% \mathrm{wO}_{3}$ concentrate. Most of geologic data from Buddington, 1929 (B 807). Detalls of USBM exploration; $4,660.5 \mathrm{ft}$. of diamond-drill holes and $82 \mathrm{ft}$. of crosscuts and ralses. Scheelite nearly all in Lindeborg vein; wuch of scheelite-bearing ore has been stoped out. (In this report the Ickis vein of Buddington is called the Rlverview vein.]. West and Benson, 1955 (B 1024-B), p. 30 -- Data from Buddington, 1929. (B 807), P. 43 .

p. 35 - Sample of mil1 concentrate contained $0.001 \%$ eU.

p. 42 -- Spectrographic analys1s of sample of mill concentrate showed the major components to be lead, copper, silver, 1ron, and silicon.

p. 44 -- No radioactive anomalies found. Mine has produced lead, sllver, and gold.

Byers and Sainsbury, 1956 (B 1024-F), p. 125-136 -- Scheelite known to be abundant in Hyder districe only at Riverside and Mountain View [Ketchikan quad.] properties. Scheelite-bearing deposits are mineralized shoots to quartz veins in Texas Creek Granodiorite and in inclusions of hazelton Group rocks in the granodlorite; veins are as much as $7 \mathrm{ft}$. thick and generally strike $N 40^{\circ}-60^{\circ} \mathrm{W}$ and dip $50^{\circ}-80^{\circ} \mathrm{NE}$ (at an angle to gneisalc banding of granodiorite, which generally strikes $N 85^{\circ} \mathrm{E}$ and dips steeply $N)$. Ore minerals include scheelite, galena, pyrite, tetrahedrite, pyrrhotite, chalcopyrite, sphalerite, and native gold; principal gangue mineral is quartz with minor calcite, ankerice, and barite.

Scheelite deposited in Lindeborg shear zone seems to have preferentlally replaced calcareous laminae in schist; Lindeborg vein is complex, with part a quartz fissure vein and part a replacement deposit. Production of mine, 1925-50, was 29,142 tons of ore milled that yielded minima of $2,452.5 \mathrm{oz}$. gold, 88,810 o2. silver, 75,700 lbs. copper, 2,258,200 lbs. lead, 17,900 1bs. zinc, and 3,500 units $(70,000$ lbs $) W_{3}$. Lindeborg shear zone strikes $N 45^{\circ}-55^{\circ} \mathrm{W}$, dips steeply $N$, and has been traced for $2,000 \mathrm{ft}$. along strike and through a vertical interval of more than 700 $f t$. Other veins in mine contain only rare grains of scheelite. USBM drilled 4,660 ft. of dlamond-dr111 holes and analyzed 36 core and 47 sludge samples. Percentages of wO ranged from 0.03 to 2.60 . Chances of finding more scheelite ore shoots are consldered to be good, but most probably would be smaller and lower grade than those that have been mined. 
Riverside (Mining \& Milling Co.) - Continued

Kaufman, 1958 (IC 7844), p. 13 -- Small scheelite ore bodies have been found.

Noe1, 1966, p. 53-55 -- Operated 1925-27 as a lead-silver-gold mine; from 1941 to 1946 as a tungsten mine. About 10,000 tons of tungsten ore produced, $1941-45$.

p, 63-64 -- References to Byers and Sainsbury, 1956 (B 1024-F).

Berg and Cobb, 1967 (B 1246), p. 147 -- In granodiorite and a large sheared schist lnclusion; quartz veins carrytng scheellte, lead-, zinc-, copper-, and silver-bearing sulfides, and native gold. Most production from Lindeborg shear zone in the incluston. More than 6,000 ft. of workings; explored (malnly by USBM during World War II) by about 4,600 fr. of diamond-drill holes. Production was about 3,000 oi. gold, 100,000 oz. Silver, 100,000 1bs. copper, 250,000 1bs. lead, 20,000 1bs. zinc, and 3,500 units $(70,000$ los $)$ WO .

Berg and others, 1977 (B 1403), p. 39 - About 26,000 metric tons of ore containing tungsten, gold, stlver, copper, lead, and zinc produced between 1925 and 1951 , the last year of recorded production.

p. 45 -- Tungsten ore was mined.

p. 72 - Data from Berg and Cobb, 1967 (B 1246).

Solch, 1977 (B 1425), p. 17-18 -- On the basis of detalled petrography, Smith belleves that the Lindeborg shear zone is a zone of mylonite gneiss and ultramylonite derlved from Texas Creek Granodiorite in a wider zone of cataclastic rocks rather than a schist lens along which later movement had taken place. 
Silver Bar

Hyder district

MF- $418,10 \mathrm{c}, 18$
Copper, Lead

Bradfleld Canal (18.2, 1.3)

$56^{\circ} 04^{\prime} \mathrm{N}, 230^{\circ} 08^{\prime} \mathrm{W}$

Sumary: Quartz fissure vein as much as $3 \mathrm{ft}$. thick in granodiorite contains pockets and bands sparsely to moderately mineralized with chalcopyrite and a little galena and pyrite; barite present. Includes reference to McVey.

Buddington, 1925 (B 773), p. 88 -- Reported to be a quartz fissure vein in granodiorite with pyrite, galena, and chalcopyrite.

Buddington, 1929 ( 8 807), p. 93 -- Quartz vein as much as $3 \mathrm{ft}$. wide in fissure zone in Texas Creek Granodiorite; strikes $\mathrm{N} 30^{\circ} \mathrm{W}$, dips $45^{\circ} \mathrm{E}$; exposed for length of 250-300 ft.; consists of mostly barren quartz with local pockets and bands sparsely to moderately mineralized with sulfides (mainly chalcopyrite with a little galena and pyrite) and barite. 
S1lver Bel1

Hyder district

MF $-418,10 c .15$
Copper, Lead, Zinc

Bradeleld Canal (17.6, 1.45)

$56^{\circ} \mathrm{O} 4^{\prime} \mathrm{N}, 130^{\circ} 12^{\prime} \mathrm{W}$

Sumary: Quartz fissure vein in brecciated zone in arglilite and graywacke is about $2 \mathrm{ft}$. thick and carries sparse disseminated pyrite, chalcopyrite, galena, and sphalerite; also a solid shoot of galena with a little tetrahedrite in part of vein. No data on possible silver content.

Buddington, 1929 (B 807), P. 44 -- Example of winerallzed fissure zone in tuffaceous slate and graywacke of Hazelton $G p$.

p. 97 -- Vein in brecciaced zone in argillite and graywacke; strikes $N 80^{\circ} \mathrm{W}$ and dips $N$; at a slight angle to bedding; about $2 \mathrm{ft}$. thick and consists of quartz with inclusions of country rock and sparse disseminated sulfides (pyrite, and chalcopyrtte with a little galena and sphalertte); part of vein 1 a solid shoor as much as 13 in. thlck made up mainly of galena with a little terrahedrite. No work done when visited; exposed for a distance of $50 \mathrm{ft}$.

West and Benson, 1955 (B 1024-B), P. 31 -- Data Erom above, P. 44. 
Silver Coln

Hyder district

$M F-418,100.16$
Copper, Lead

Bradfield Canal $(17.85,1.5)$

$56^{\circ} 05^{\prime} \mathrm{N}, 130^{\circ} 10^{\prime} \mathrm{W}$

Sumary: Northern part of vein about $50 \mathrm{ft}$. long following a shear zone in granodiorite is as much as $5 \mathrm{ft}$. wide and contalns galena wth a little pyrite and chalcopyrite.

Buddington, 1925 ( $B$ 773), P. 90 -- Quartz veln in granodiorice is about 50 Et. long; strikes $N 5^{\circ}$ and dips $45^{\circ}$ E. $25 \mathrm{ft}$. of veln is heavily metallized with galena; a little pyrite and chalcopyrite. Rest of vein is barren quartz. Ore shoot is Erou a few inches to 5 ft. wide. Buddington, 1929 (B 807), p. 95 -- Quartz vein in granodiorlte is about 50 $\mathrm{ft}$. long and strikes $\mathrm{N} 5^{\circ} \mathrm{W}$ and dips $45^{\circ} \mathrm{E}$; ore shoot in northern part of vein is from a few inches to $5 \mathrm{ft}$. wide and contains galena with a ixtrle pyrite and chalcopyrite. In granodiorice along a shear zone; malachite along fracture surfaces in footwall. 
S1lver King

Hyder distrfct

$M F-418$, loc. 8
Copper, Gold, Lead, Silver, Zinc;

Barite

Bradfield Canal (16.95, 1.4)

$56^{\circ} 04^{\prime} \mathrm{N}, 130^{\circ} 16^{\prime} \mathrm{W}$

Summary: Quartz fissure vein 6-30 in. wide has 2-8 in. of solid sulfides, including sphalerite, galena, pyrite, chalcopyrite, tetrahedrite, and a litrle arsenopyrite; barire also present. In graywacke and argillite cut by quartz diorlte dike. Sample of galena reported to have assayed $1.28 \mathrm{oz}$, a ton gold, $5.96 \mathrm{oz}$ a ton silver, $55.2 \%$ lead, and $2.2 \%$ copper. Could not be found in 1970's investigatioa. See also Marietta; may be the same.

Buddington, 1929 (B 807), p. 99-100 -- 2 stripped exposures, probably on the same quartz fissure vein (strike $N 35^{\circ} \mathrm{W}$, dip $35^{\circ} \mathrm{NE}$ ). Vein is 6-30 in. wide and has $2-8 \mathrm{in}$. of solid sulfides, including sphalerite, galena, pyrite, chalcopyrite, tetrahedrite, and a little arsenopyrice; some barite also. Country rock is graywacke and argillite cut by a quartz diorite dike. Sample of galena ore reported to have assayed $1.28 \mathrm{oz}$. gold and 5.96 oz. silver a ton, $55.2 \%$ lead, and $2.2 \%$ copper.

Berg and others, 1977 (B 1403), p. 38-39, 99-100 -- Data from above; could not be found. Reported to be near Marietta, but lower. 
Silver Stat

Hyder district

MF-418, 10C. 15
Gold, Lead, Zinc

Bradfield Canal $(17.6,1.45)$

$56^{\circ} 04^{\prime} \mathrm{N}, 130^{\circ} 12^{\prime} \mathrm{W}$

Sumary: Quartz velns and veinlers in arglllite and granodiorite contain local concentrations of galena, sphalerite, and pyrite with smaller amounts of pyrrhorlie and arsenopyrite. Picked sample said to have yielded an ounce of gold per ton.

Buddington, 1925 (B 773), P. 89-90 -- 2-Et.-wide shear zone in granodlorite strikes about $\mathrm{N} 10^{\circ} \mathrm{E}$ and dips $55^{\circ} \mathrm{E}$; contains pyrtte and galena. Picked sample said to have yielded an ounce of gold per ton.

Buddington, 1929 (B 807), P. 97 -- Claims staked along contact between Texas Creek Granodlor1te and argllilte; quartz velos in fissure zones both above and below contact. 2 veins in gramodlorite in the same flssure zone consist of quartz as much as a foot wide carrying mainly galena and pyrite; explored by 30-Et. ad1t; strike about $N$ and dip $55^{\circ}$ E. Vexn zone in argillite conslsts of quartz atringers about parallel to bedding (strike about $N 70^{\circ} \mathrm{W}$ ) locally minerallzed with galena, sphalerite, pyrice, ad smaller amounts of pyrrhotite, arsenopyrite, and freiberglce. 
Stampede

Hyder districe

MF-418, 10c. 8
Copper, Gold, Lead, Silver, Zinc

Bradfield Canal (16.95, 1.3)

$56^{\circ} 04^{\prime} \mathrm{N}, 130^{\circ} 16^{\prime} \mathrm{W}$

Summary: Flssure veins in a shattered zone, mineralized quartz stringers In shear zones, sulfide stringers, and fractures in an aplite dike carry sparse galena, sphalerlte, pyrite, and chalcopyrite; very small amounts of silver; a trace of gold in one sample. Graywacke and slate country rock. Very little development. Includes reference to Dugas.

Buddingron, 1929 (B 807), 9. 99 -- At Dugas prospect country rock is graywacke with an intercalated zone of black slate; strike is $70^{\circ}-80^{\circ} \mathrm{E}$ and the dip to the north. Mineral deposits are (l) flssure veins in shatcered zone cutting across bedding, (2) mineralized quartz stringers in shear zones parallel to bedding, and (3) stringers of sulfide (usually brown sphalerite) paraliel to bedding. No ore shoot of any size. Sulfides include sphalerite, galena, pyrite, and chalcopyrite. Fracture surfaces in an aplite dike are faced with some sulfldes. Only development 152 open cuts.

Berg and other5, 1977 (B 1403), P. 38-39 -- Quartz fissure velns, sulfide stringers, and a mineralized aplite dike in graywacke and black slate of Hazeltou(?) Gp. contain galena, sphalerite, and chalcopyrite. Explored by 2 open cuts. Originally staked as Dugas in 1925.

p. 76-77, 79-80 -- Some or all of ground was staked and restaked several thes between 1923 and 1958. 3 pits alined along a poorly defined shear zone that strikes $N 45^{\circ}$ E and dips steeply $N W$. Sulfides include swall amounts of galena and sphalerite and traces of chalcopyrite. Quartz vein nearby carries a trace of malachite and chalcopyrlte. Highest precious-metal assays from 5 samples were 0.05 ppm gold and 30 ppm silver. [Detalls of descriptions in various parts of this report do not agree.] 
Stoner (Gold \& Silver Minlng Co.) Gold, Lead, Sllver, Zinc

Hyder district

Bradfield Canal (19.2, 0.85$)$

$M F-418,100.24$

$56^{\circ} 02^{\prime} \mathrm{N}, 130^{\circ} \mathrm{O} 2^{\prime} \mathrm{W}$

Summary: Three types of deposits on property: (1) quartz-calcite veins and disseminated deposits in greenstone; (2) sparsely mineralized quartz fissure velns in or near contacts between slate and granitic dikes; and (3) seams, disseminations, and fracture facings in quartz porphyry dikes. Sulfides include pyrite, sphalerite, galena, tetrahedrite, and pyrrhotite; 28 much as about half an ounce of gold and 20,5 oz. Sllver a con reporced. Explored by open cuts and a lS-Et. Shate.

Westgace, 1922 (B 722), p. 131-132 -- Shallow cuts in several places on group of 12 claims. Bedrock greenstone, some pyrthotitized. Sulfides include pyite, sphalexite, galena, and pyrrhotite; a little gold, as much a $20.5 \mathrm{oz}$, a con silver, and $28 \%$ lead reported.

Buddington, 1925 (B 773), p. $74 \sim$ Replacement and disseminated deposit in greenstone; this type of deposit contains pyrite, galena, sphalerite, chalcopyrite, and pyrthotice.

p. 83 -- Open cut in either slliclfied greenstore or a felsite sheet. Disseminated pyrtte, locally a little galena, and common veinlets of calcite. Best assay reported to be about half an ounce of gold per ton.

Buddington, 1929 (B 807), p. 43 -- Example of disseminated and lenticular replacement type of deposit.

p. 89-90 -- Councry rock ts Hazelton Gp., mainly greenstone. Cut by granticic dikes associated with Texas Creek and Hyder batholiths. Mineral deposits are (1) veins and disseminated deposits (quartz-calcite gangue) in greenstone; (2) aparsely minerallzed quartz fissure veins in or near contacts between slate and dikes; and (3) seaws, disseminated deposics, and fracture facings in quartz porphyry. Most work has been on a deposit of first type; shaft $15 \mathrm{ft}$. deep and open cuts. Sulfide winerals are pyxice, sphalerite, galena, tetrahedrite, and pyrthotite. Some specimens (not from deposit with most development) have assayed $\$ 6$ co $\$ 8$ a ton In $_{\text {gold }}$ and silver.

West and Benson, 1955 (B 1024-B), p. 31 -D Data from Buddington, 1929 (B 807), p. 74 . 
Stoner-Clegg-0' Rourke

Hyder district

$M F-418,10 C .24$
Copper, Lead, Zinc

Bradfield Canal (19.2,0.85)

$56^{\circ} 02^{\prime} \mathrm{N}, 130^{\circ} 02^{\prime} \mathrm{W}$

Sumary: Greenstone contains disseminated pyrite and pyrrhotite and calcite veialets carrying sphalerite, pyrite, and galena and smaller amounts of pyrrhotite, chalcopyrite, and tetrahedrtte. Explored by open cuts and a 75-ft. tunnel.

Buddington, 1929 (B 807), p. 88 -- Country rock greenstone with calcite veinlets carrying sphalerite, pyrite, galena and small amounts of pyrrhotice, chalcopyrite, and tetrahedrite. Explored by tunnel $75 \mathrm{ft}$. long and open cuts. Some of greenstone contains disseminated pyrite and pyrrhotite. 
Sunset

Hyder district

MF-418, loc. 12
Lead

Bradfield Canal ( $17.5,0.5)$

$56^{\circ} 01^{\prime} \mathrm{N}, 130^{\circ} 13^{\prime} \mathrm{W}$

Summary: Quartz veins in granodiorite near a roof pendant of argillite and graywacke contain small amounts of galena and pyrite. Little exploration.

Buddington, 1929 (B 807), 8.109 -- 2 mineralized quartz veins in Texas Creek Granodiorite near an isolated roof pendant of argillite and graywacke strike about $\mathrm{N} 50^{\circ} \mathrm{W}$ and dip steeply $\mathrm{NE}$. One vein is $1-3$ ft. wide, has been traced for about $300 \mathrm{yds}$, and contains local ore shoots with galena and pyrite; at one place a shattered zone $20 \mathrm{ft}$. wide contains abour $5 \mathrm{ft}$. of quartz stringers carrying moderate amounts of galena and pyrite. The other vein 1 s about $3 \mathrm{ft}$. wide, has been traced for abour $200 \mathrm{yds}$., and contains locally disseminated pyrite and a lens $12 \mathrm{ft}$. Long and 4 in. thick of pyrite, galena, and barice. Exploration was by a little surface stripping. 
Swede

gyder districe

$M F-418,100.23$
Copper, Lesd, Zinc

Bradfield Canal $(19.15,0.7)$

$56^{\circ} 02^{\prime} \mathrm{N}, 130^{\circ} 03^{\prime} \mathrm{W}$

Sumary: Table shows pyrxte, galena, sphalerite, chalcopyrite, and pyrrhotice. Description says property is reporced to be similar to Daly-Alaska, where deposits carry chalcopyrite, sphalertce, and argentiferous galena. May be the same as Hobo or Portland.

Buddington, 1925 (B 773), p. 74 -- Replacement and disseminated deposit in greenstone contains pyrite, galena, sphalerite, chalcopyrite, and pyr rhotite.

p. 78 - 6 claims said to be similar to Daly-Alaska. 
Swennings Greenpoint

Hyder district
Lead, Molybdenum, Silver

Bradfield Canal (17.05, 0.5)

$56^{\circ} 01^{\prime} \mathrm{N}, 130^{\circ} 16^{\prime} \mathrm{W}$

Summary: Quartz veins in hornfels 3.5 m from contact between rocks of Hazelton(?) Gp. and Hyder Quartz Monzonite contain galena and molybdenite; as much as 100 ppm silver; no gold.

Berg and others, 1977 (B 1403), P. 40-41 -- Quartz veins in hornfels of Hazelcon(?) Gp. near (15 m) conkact with Hyder Quarcz Monzonite contain galena and molybdenite; veins strike $\mathrm{N} 30^{\circ} \mathrm{W}$ and dip $65^{\circ}-70^{\circ} \mathrm{NE}$. p. 92-93 -- Same data as above. Assays of 4 samples showed as much as 100 ppr silver; no gold.

\section{RECEIVED}

Nov 2 197?:

Diy. Ot Gengugicisi Suryey Allitiorng:- 
Texas Discovery

Hyder district

$M F-418$, loc. 15
Copper, Gold, Lead, Silver

Bradfield Canal $(17.6,1.45)$

$56^{\circ} 04^{\circ} \mathrm{N}, 230^{\circ} 12^{\prime} \mathrm{W}$

Summary: Quartz fissure vein in granodiortte is $1-14$ in. thdck and contalns pyrite, galena, pyrrhotite, and sparse chalcopyrite; picked sample reported to have contained $30 \%$ lead, about 1.06 .02 . a ton gold, and $\$ 6$ a ton in silver. A nearby quartz stringer $42 n$. thick contains galena and chalcopyrite.

Buddington, 1925 (B 773), p. 74 -- Quartz fissure vein In granodjorite contains pyrtte, galena, and chalcopyrite.

p. 90-9l -- Quartz vein $1-14$ in. wide pinches out to $N$; strikes $\mathrm{N} 30^{\circ} \mathrm{W}$ and dips $45^{\circ}-60^{\circ} \mathrm{NE}$. Contains pyrite, galena, pyrrhotite, and sparse chalcopyrite. Assay of plcked sample sald to have shown $30 \%$ lead, $\$ 22$ a ton in gold [about $1.06 \mathrm{oz.}$ ], and $\$ 6$ a ton in silver. Staked in 1923.

Buddington, 1929 (B 807), P. 98 -- Most of data as above. Strike given as N $15^{\circ}-30^{\circ} \mathrm{W}$. Nearby quartz stringer 4 ín. thick strikes $\mathrm{N} 50^{\circ} \mathrm{W}$, dips $45^{\circ} \mathrm{NE}$, and carries galena and chalcopyrite.

Byers and Salasbury, 1956 (B 1024-F), p. 140 -- Examination with ultraviolet lamp filed to find scheelite. 
Titan ( $\&$ Salmon River Syndicage)

Ryder distrtee

MF $-418,100,23$
Copper, Gold, Lead, Silver, ZInc

Bradfield Canal ( $19.25,0.7)$

$56^{\circ} 02^{\prime} \mathrm{N}, 130^{\circ} 03^{\prime} \mathrm{W}$

Sumary: Country rock is greenstone and intercalated slate cut by porphyry dikes. Principal deposit is in a shear zone in an alcered pyritiferous porphyry dike with much included country rock; quartz veins as much as $2 \mathrm{ft}$. thick contain disseminated sphalerite and lesser amounts of galena, pyrite, and chalcopyrite; plcked samples from outcrop sald to carry considerable gold and silver; samples from underground workings were leaner. Explored by about $500 \mathrm{ft}$. of adit and crosscuts. Another quartz vein (In greenstone?) carries a little galena, sphalerite, pyrlte, and chalcopyrtice; very 11ttle work done there. Shear zone in greenstone carrles arsenopyrite and a little galena. Prospect staked in 191.7; last reported work in 1928. No record of production.

Buddington, 1925 (B 773), P. 74 -- Quartz vein and veinlike replacement deposit in quartz porphyry (felstee). Deposits of thls type contain pyrite, galena, sphalerite, chalcopyrite, and pyrrhotite.

p. 77 - Information supplied by one of owners. Property staked in 1917. Developments include $400 \mathrm{ft}$. of tunnel. Cut a body of quarez $12 \mathrm{ft}$. wide carrying abour $\$ 4$ [about $0.19 \mathrm{oz}$. ] gold and $6 \mathrm{oz}$. 5ilver per ton; sparse galena, pycite, and sphalerite. Country rock 1s quartz porphyry similar to that at Premier [in B.C.]. Plcked samples of rich stringers to porphyry sald to assay as much as $4-1 / 2$ oz. gold a tor.

Buddington, 1929 (B 807), p. 72-74 - Country rock is greenstone and intercalated slate of Hazelton Gp. intruded by porphyry dikes assoclated with the Texas Creek and Hyder batholiths. Most of the work (about $550 \mathrm{ft}$. of adit and crosscuts) has been in a shear zone containing quartz veins as much as $2 \mathrm{ft}$. thlck in a large NW trending sheared and altered porphyry dike with many included layers of slaty rock and greenstone; zone traced for 250 yda. on surface; strlkes $\mathrm{N} 50^{\circ}-60^{\circ} \mathrm{W}$, dips $45^{\circ} \mathrm{SW}$. Porphyry impregnated with pyrtte; quartz contalns dissemfnated sphalerite and lesser amounts of galena, pyrite, and chalcopyrite. Picked samples from outcrops reportedly were high in gold and silver; lower assays from materlal in work1ngs. Elsewhere on property a sheared quartz vein [10 greenstone?] 7-10 ft. thick that apparently stríkes NE and dips $30^{\circ}$ SW 1 s crossed by a granodlorite porphyry dike. Local shoots in walls of vein carry a iltele disseminated galena, sphalerite, pyrite, and chalcopyrite; very lutele work has been done here. Another shear zone in greenstone carries considerable arsenopyrite and a litele galena.

Swich, 1930 (B 813), p. 15 - Development, 1928.

West and Benson, 1955 (B 1024-8), P. 44 -- No radionctivity anomalles found in traverse of drifts.

Byers and Salnsbury, 1956 (B 1024-F), p. 140 -- Search with ultraviolet lamp failed to find any scheelite. 
(Unuk R.)

Hyder district

\section{Copper}

Bradfield Canal $(12.0,6.0)$ approx.

$56^{\circ} 20^{\prime} \mathrm{N}, 130^{\circ} 46^{\prime} \mathrm{W}$ approx.

Summary: 2-ft. veln contains pyrite, pyrrhotite, and chalcopyrite. No other laformation.

Wedow and others, 1952 (OF 51), p. 57 -- "Pyrite, pyrrhotite, and chalcopyrite occur in a 2 -foot vein in the Unuk River about a mile below the international boundary." 
Virginla

Hyder district

$M F-418,100.24$
Copper, Gold, Lead, Zinc

Bradfield Canal $(19.2,0.85)$ $56^{\circ} 02^{\prime} \mathrm{N}, 130^{\circ} 02^{\prime} \mathrm{W}$

Sumbary: Mineralized shear zone in greenstone is several feet wide; ore shoot is nearly solid sulfides, including pyrrhotice, sphalerite, pyrite, and a little galena and tetrahedrite in quartz gangue; selected samples reported to have run as high as $4-1 / 2$ oz. a ton gold. Developed by about $300 \mathrm{ft}$. of crosscut and drift. Blsewhere on property mineralized greenstone contains small amounts of galena, pyrlte, sphalerice, chalcopyrite, and pyrrhotite. No record of any production.

Buddlugton, 1925 (B 773), p. 74 -- Replacement and disseminated deposits Ia greenstone contain pyrite, galena, sphalerite, chalcopyrite, and pyrrhotite.

p. 84 -- Reported that claims were staked in 1919. 600-700 ft. of tunnel and crosscuts. 22-16 ft. of a zone $50 \mathrm{ft}$. wide is mineralized with sulfides. Ore sald to average $\$ 4-\$ 6$ a ton, mainly in gold. Selected samples have ylelded as wuch as $4-1 / 2$ oz. gold per ton. Buddington, 1929 (B 807), p. 43 -- Example of disseninated and lenticular replacement type of deposit.

p. 88-89 -- Mineralized ore shoot in shear zone several $\mathrm{ft}$. thick in greenstone strikes $\mathrm{N} 50^{\circ} \mathrm{W}$, dips $S$; almost solid sulfide consisting of pyrrhotite, sphalerite, pyrite, and a little galena and tetrahedrite in quartz gangue. Developed by a little more than $300 \mathrm{ft}$. of crosscut and drifts. Selected samples of ore regorted to have run as much as 4-1/2 oz. gold per ton. Elsewhere on property minera1ized greenstone contains small amounts of galena, pyrite, sphalerite, chalcopyrite, and pyrrhotite.

West and Benson, 1955 (B 1024-B), P. 31 -- Data from Buddington, 1929 (B 807), p. 43. 
Western

Hyder district

$\mathrm{MF}-418,10 \mathrm{c} .23$
Copper, Lead, Zinc

Bradfield Canal ( $19.15,0.7$ )

$56^{\circ} 02^{\prime} \mathrm{N}, 130^{\circ} 03^{\prime} \mathrm{W}$

Sumary: Disseminated pyrite, chalcopyrite, galena, and sphalerice in a lode at least $15 \mathrm{ft}$. wide in silicified schistose tuff. See also Daly-Alaska, of which Western may have become a part.

Chapin, 1916 (B 642), p. 97 -- Bertha and Western claims being developed in 2915 on a NE-trending lode at least 15 ft. wide as exposed in a surface cut; In silicified schistose tuff; disseminated pyrite, chalcopyrite, galena, and sphalerite.

Mertle, 1921 (B 714), p. 142 - Quotacion from above. 
Unnamed occurrence

Copper, Gold, Lead

Hyder district

Bradfield Canal (16.75, 1.2$)$

$56^{\circ} 03^{\prime} \mathrm{N}, 130^{\circ} 17^{\prime} \mathrm{W}$

Summary: Quartz-albite vein and quartz stringers in metamorphic rocks contain pyrite and very small amounts of galena and chalcopyrite;

$0.05 \mathrm{ppm}$ gold in a chip sample. May be on same ground as old Sunset or Blasher prospects.

Berg and others, 1977 (B 1403), p. 133-134 ( $M-10)$-- Quartz-albite vein and intersecting zone of quartz stringers in small area underlain by metamorphic rocks of liazelton(?) GP. Vein strikes $\mathrm{N} 50^{\circ} \mathrm{W}$, dips $55^{\circ} \mathrm{SW}$, and $1 \mathrm{~s}$ about $60 \mathrm{~cm}$ wide. Vein and fracture system contain as much as about 2\% pyrite and very small amounts of galena and chalcopyrite. Composite chip sample contained $70 \mathrm{ppm} \mathrm{Cu}, 80 \mathrm{ppm} \mathrm{Pb}, 30 \mathrm{ppm} \mathrm{Zn}$, and 0.05 ppon Au. May be on Sunset or Blasher. 
Unnamed occurrence

Hyder district
Copper, Gold, Silver

Bradf leld Canal (15.75, 1.05)

$56^{\circ} 03^{\prime} \mathrm{N}, 330^{\circ} 24^{\prime} \mathrm{W}$

Sumary: Quartz pods in Iron-stalned metagraywacke contain pyrrhotite, traces of chalcopyrite, and small amounts of gold and silver.

Berg and others, 1977 (B 1403), p. 133 (M-9) -- Quartz pods in iron-stained metagraywacke contain pyrrhotite add traces of chalcopyrite; as much as $1.5 \mathrm{ppm} \mathrm{Ag}$ and $0.05 \mathrm{ppm} \mathrm{Au}$ in samples. Pods strike $\mathrm{N} 30^{\circ} \mathrm{E}$, dip $80^{\circ} \mathrm{SE}$; foliation of country rock strikes $\mathrm{N} 60^{\circ} \mathrm{E}$, dips $70^{\circ} \mathrm{NW}$. In general area where claims were staked on Banded Mtn, in late 1920's. 
Unnamed occurrence

Hyder district
$\mathrm{RE}$

Bradfield Canal (14.75, 2.1)

$56^{\circ} 07^{\prime} \mathrm{N}, 130^{\circ} 30^{\prime} \mathrm{W}$

Sumary: Accessory minerals in foliaced hornblende granodiorthe include sphene and allanite.

Solth and others, 1977 (MF-825), sample 35010 -- Accessory minerals in medium-grained strongly follated hornblende granodiortte include sphene and allanite. 
Unnamed occurrence

Hyder district
$R E$

Bradfield Canal (12.5, 2.5) $56^{\circ} 08^{\prime} \mathrm{N}, 130^{\circ} 43^{\prime} \mathrm{W}$

Sumary: Accessory minerals th slightly porphyritic biotite quartz monzonite Include sphene and allanite.

Smith and others, 1977 (MF-825), sample 35019 - Accessory sphene, allandte, and opaque minerals in slightly porphyritic biotite quartz monzonite with weak schlieric structure and vague compositional banding. 
Unnamed occurrence

Hyder district
Silver

Bradfield Canal (13.65, 3.25)

$56^{\circ} 11^{\prime} \mathrm{N}, 130^{\circ} 36^{\prime} \mathrm{W}$

Summary: Quartz-epidote veinlets in hornblende gneiss contain as much as 2.0 opm silver.

Berg and others, 1977 (B 1403), p. 140 (G-50) -- Quartz-epidote veinlets in hornblende gneiss contaln 0.5-2.0 ppm silver. Spectroscoplc analyses indicated the presence of small amounts of copper, lead, zlnc, molybdenum, and tungsten. 
Synonyms, Claim Names, Operacors, and owners

Many mines and prospects have undergone changes in both cheir own names and in the names of their operacors and owners. All names that appear in the cited references appear in this sumary either in the first section as occurrence names or in this as synonyms. 


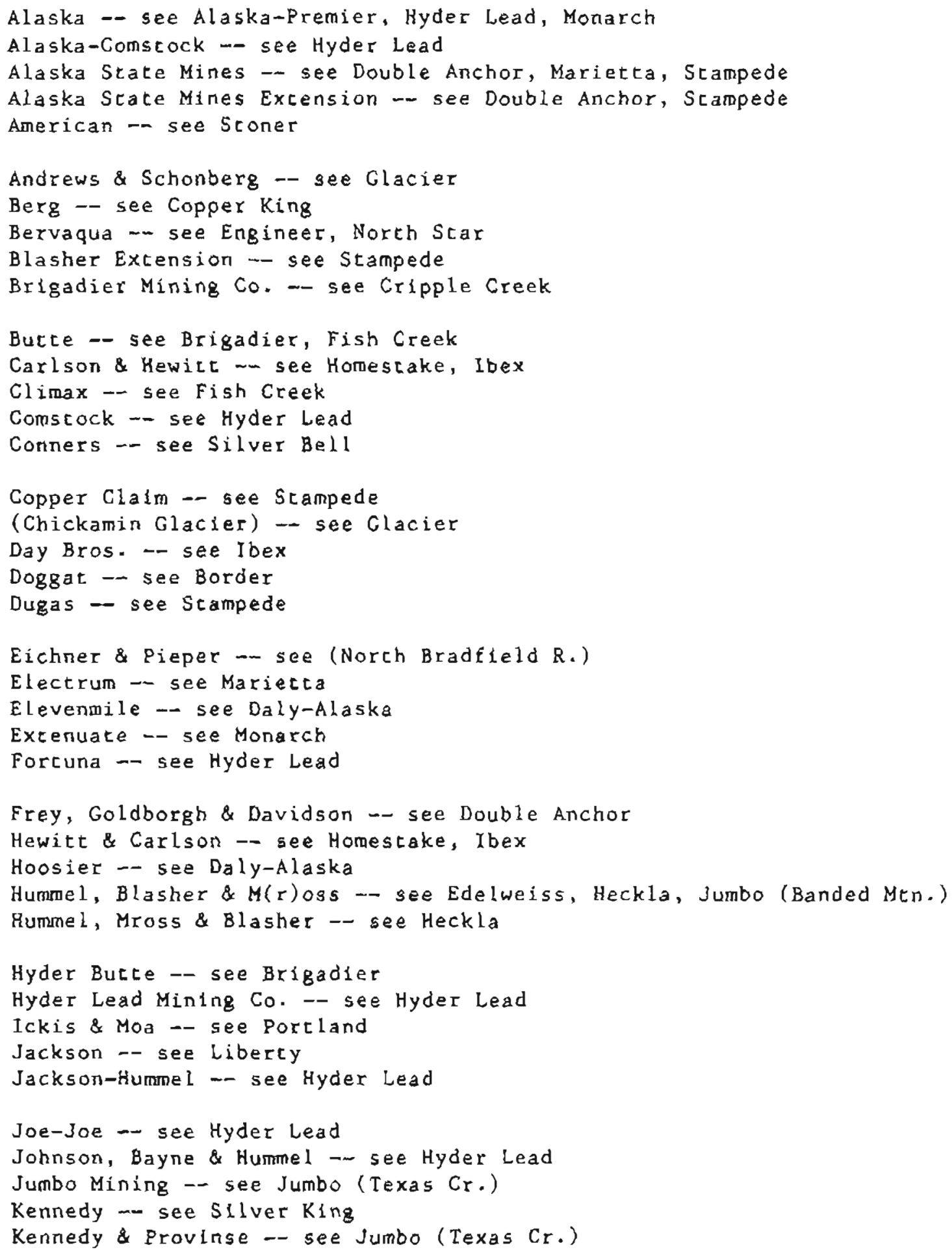




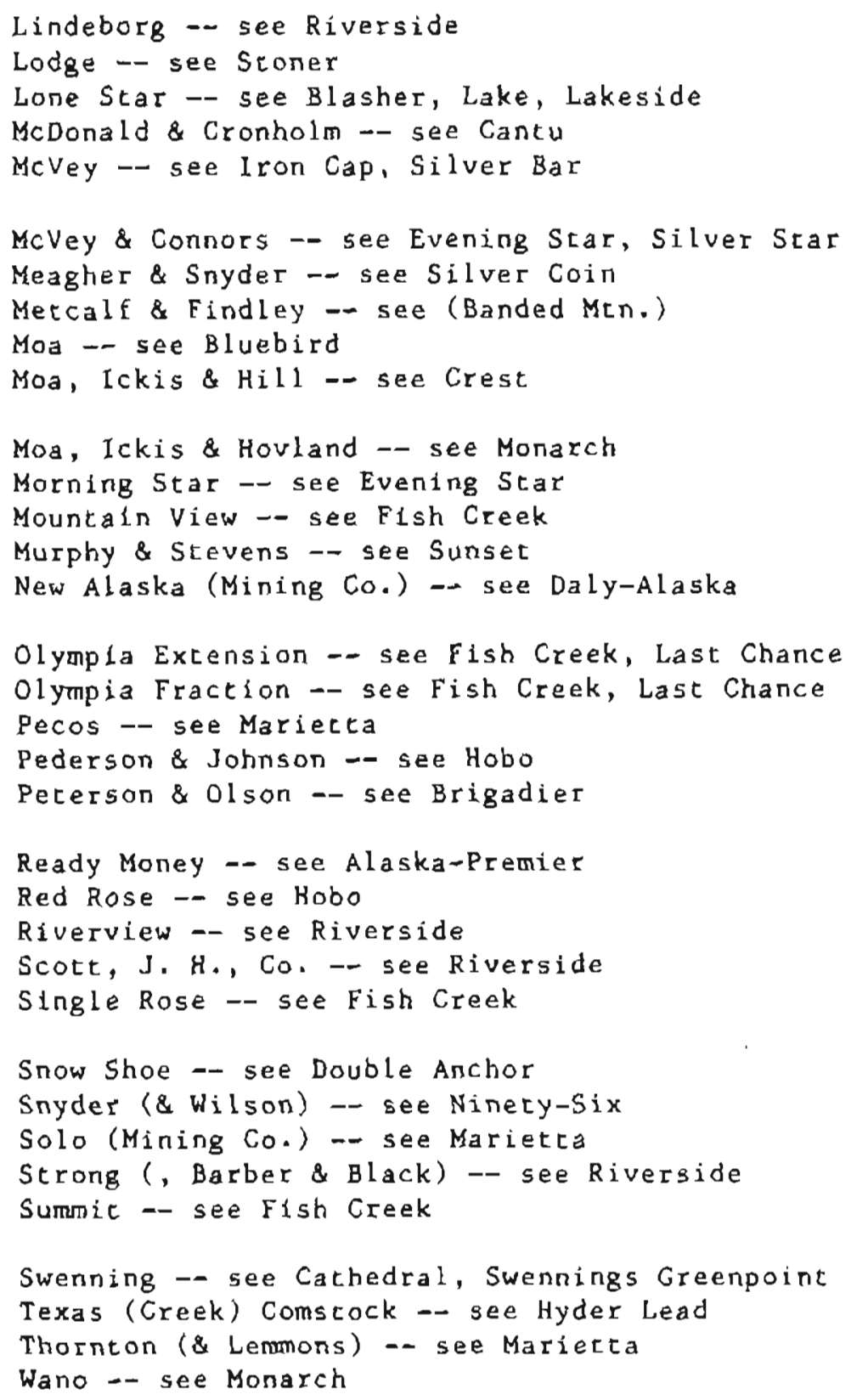




\section{References Cited}

References aro Listed in standard bibllograbic format alphebetically by euthor and, seconderily, chronologically 19 an autbor prepazed wore than one report of map. This section was prepared by stacking bibliogrephy cards in a document protector and duglicating them on an offlce copylag machlae. Th1s procedure maked retyping unnecessery, but bea the disadvantages that the edges of cards ray reproduce as borizontal lines between entries ana tbat margins and specing are not constant. 
Bain, H. F., 1946, Alaska's minerals as a besto for industry: U.S. Bureau of Mines Information Clrcular $7379,89 \mathrm{p}$.

Berg, H. C., and Cobb, H. H., 1967, Metsli1ferous lode deposits of Alaske: U.S. Geologlcal Survey Bulletin 1246, 254 p.

Berg, H. C., Elliott, R. I., Smith, J.G., Pittman, T. L., and Kimball, A. L., 1977, Mineral resources of the Granite Flords wilderness study erea, Alaska, with a section on aeromagnetic data by Andrew Griscom: U.S. Geol. Survey Bull. 1403, 151 p.

Brooks, A. H., 1923, The Alaska mining Industry in 1921: U.S. Geologlcal Survey Bulletin 739, p. 1-44.

Buddington, A. F., 1925, Mineral investigations in southeastern Alaska: U.S. Geological Survey Bulletin 773, p. 71-139.

Buddington, A. F., 1926, Mineral investigations in southeastern Alaska: U.S. Geological Survey Bullerin 783, p. 41-62.

Buddington, A. F., 1929, Geology of Hyder and vicinity, southeastern Alaska, with a reconnaissance of Chickamin River: U.S. Geol. Survey Bul1. 807, $124 \mathrm{p}$.

Buddington, A. F., and Chapin, Theodore, 1929, Geology and mineral deposits of southeastern Alaska: U.S. Geological Survey Bulletin $800,398 \mathrm{p}$.

Byers, F. M., Jr., and Sainsbury, C. L., 1956, Tungsten deposits of the Byder district, Alaska: U.S. Geol. Survey Bull. 1024-F, p. 123-140.

Chapin, Theodore, 1916, Mining developments in soucheastern Alaska: U.S. Geological Survey Bulletin 642, p. 73-104.

Chapin, Theodore, 1918, Mining developments in the Ketchikan and Wrangell mining districts: U.S. Geological Survey Bulletin 662, p. $63-75$.

Cobb, E. H., 1972, Metallic mineral resources map of the Bradfield Camal quadrangle, Alaske: U.S. Geol. Survey Misc. Fiela Studies Map MF-418, 1 sheet, scale 1:250,000.

Kaufman, Alvin, 1958, Southeastern Alaska's mineral industry: U.S. Bureau of Mines Information Circular 7844, $37 \mathrm{p}$.

Lovering, T. G., 1972, Jasperold in the United Stater - Its tharacteristics, orlgin, and economic significance: U.S. Geol. Survey Prof. paper 110,164 p.

Mackevett, E. M., Jr., and Blake, M. C., JY., 1963, Geology of the Nortb Bradfield River iron prospect, soutbeastera Alaska: U.S. Geol. Survey Bull. 1108-D, p. DI-DEl. 
Mertie, J. 8., Jr., 1921 , Notes on the salmon-Unuk River region: U.S. Geol. Survey Bull. 714, p. 129-142.

Moff1t, F. R., 1927, Mineral industry of Alaska in 1925: U.S. Geological Survey Bulletin 792, p. 1-39.

Noel, G. A., 1966, The productive mineral deposits of southeastern Alaska, In Alaska Division of Mines and Minerals, Report for the year 1966: Juneau, Alaska, P. 51-57, 60-68.

Smitb, J. G., 1977, Geology of the Ketchikan D-1 and Bradfield Caral A-1 quadrangles, southeastern Alaska! U.S. Geol. Survey Bull. $1425,49 \mathrm{p}$.

Suith, J. G., Ell1ott, R. I., Berg, R. C., and Wigeins, B. D., 1977, Map showing general geology and location of chemically and radiometrically analyzed samples in parts of the Ketchikan, Bradifield Canal, and Prince Fupert quadrangles, southeastem Alaska: U.S. Geol. Survey Misc. Field Studies Map MF-825, 2 sheets, scale $1: 250,000$.

Smich, P. S., 1926, Mineral industry of Alaska in 1924: U.S. Geological Survey Bullecin 783 , p. 1-30.

Sinith, P. S., 1929, Mimeral Industry of Alaska in 1926: U.S. Geor logical Survey Bulletin 797, p. 1-50.

Smith, P. S., 1930, Mineral industry of Alaske in 1927: U.S. Geological survey Bulletin 810 , p. 1-64.

Smith, P. S., 1930, Mineral industry of Aleska in 1928: U.S. Geological Survey Bulletin 813, p. 1-72.

Smith, P. S., 1932, Mneral industry of Alaska in 1929: U.S. Geological Survey Bulletin 824 , p. 1-81.

Smith, P. S., 1933, Mineral Industry of Alaska in 1930: U.S. Geological Survey Bulletin 836, p. 1-83.

Smith, P. S., 1933, Mineral industry of Alaska in 1931: U.S. Geological Survey Bulletin 844-A, p. 1-82.

Smith, P. S., 1934, Mineral industry of Alaska in 1932: U.S. Geologlcal Survey Bulletin 857-A, p. 1-91.

Smith, P. S., 1934, Mineral industry of Alaska in 1933: U.S. Geologicel Survey Bulletin 864-A, P. 3-94.

Smith, P. S., 1937, Mineral Industry of Alaska in 1935: U.S. GeoloBical Survey Bulletia 880-h, p. 1-95.

Smith, P. S., 1938, Mineral industry of Alaska 10 1936: U.S. Geological Survey Bulletin 897-A, P. 1-107. 
Smich, P. S., 1942, Dccurrences of molybdenum minerals in Alaska: U.S. Ceological Survey Bulletin 926-C, p. 161-210.

Smith, P. S., 1942, Mineral industry of Alaske in 1940: U.S. Geological Survey Bulletin 933-A, p. 1-102.

Thorne, R. L., Mutr, N. M., Erickson, A. W., Thomas, B. I., Heide, H. E., and Wright, H.S., 1948, Tungsten deposits In Alaska: U.S. Bur. Mines Rept. Inv. 4174, 22 p.

Wedow, Helmuth, Jr., White, M. G., and Moxham, R. M., 1952, Interfim report on an appraisal of the uranium possibilities of Alaska: U.S. Geological Survey Open-file Report 51, $123 \mathrm{p}$.

West, W. S., and Benson, P. D., 1955, Investigations for redionctive deposits in southeestern Alaska: U.S. Geol. Survey Bull. 1024-8, p. $25-5$ T.

Westgate, $L_{i} \cdot G_{i}, 1922$, Ore deposits of the Salmon River district, Portland Canal region: U.S. Geol. Survey Bull. T22, p. 117-140. 